\title{
Semiotika Foto Agen Perubahan
}

\author{
Kurnia Setiawan ${ }^{1}$, Ninawati Lihardja², Ruby Chrissandi ${ }^{3}$ \\ Fakultas Seni Rupa dan Desain, Universitas Tarumanagara ${ }^{1,3}$ \\ Fakultas Psikologi, Universitas Tarumanagara ${ }^{1}$ \\ kurnias@fsrd.untar.ac.id
}

\begin{abstract}
Para pimpinan mahasiswa yang bergerak turun ke jalan pada tahun 98 dapat disebut sebagai agen perubahan. Saat ini menjelang peringatan 20 tahun peristiwa reformasi, mereka sudah berusia 40-an dan telah memilih bidang pekerjaannya masing - masing. Penelitian ini bersifat kualitatif, dibuat dalam rangka merekam para agen perubahan setelah duapuluh tahun peristiwa reformasi 98. Bagaimana menampilkan karakter mereka melalui media fotografi ? Pendokumentasian yang dilakukan sebagai kelanjutan dari pemotretan dan wawancara yang pernah dilakukan pada tahun 2008 yang kemudian dipamerkan dengan judul "10 Years Later". Penelitian ini menggunakan pendekatan/metodologi visual. Analisa yang dipakai berdasarkan teori semiotik Charles Sanders Peirce. Subyek penelitian dipilih secara khusus (perpusive sampling), yaitu para agen perubahan yang berperan sebagai simpul massa (pemimpin) dari beberapa kampus yang tergabung dalam gerakan mahasiswa Front Aksi Mahasiswa untuk Reformasi dan Demokrasi (Famred) pada tahun 98 . Hasil penelitian berupa foto potret para agen perubahan. Penelitian ini diharapkan dapat memberikan manfaat berkenaan dengan pengembangan keilmuan, khususnya desain komunikasi visual.
\end{abstract}

Kata kunci: reformasi, agen perubahan, semiotik, foto potret

\section{PENDAHULUAN}

Duapuluh tahun setelah reformasi digulirkan Indonesia sudah merdeka lebih dari 70 tahun serta mengalami 7 kali pergantian presiden. Dalam waktu 7 bulan setelah Seoharto jatuh telah terjadi lebih dari 900 aksi di Indonesia. Diperkirakan ada 300 pejabat pemerintah, terutama di pedesaan yang dipaksa meletakan jabatnnya selamaa periode Mei - juli 1998. (Lane, 2014, p.274, p. 319) Reformasi telah membuka jalan menuju Indonesia yang lebih demokratis, terbuka sehingga proses pergantian kekuasaan mengalir lebih lancar. Sayangnya tidak semua agenda reformasi dapat direalisasikan. Masih terjadi sekat - sekat sektarianisme yang menimbulkan konflik horizontal yang mengancam pluralitas bangsa ini. Korupsi berubah bentuk dan merajalela. Pendidikan belum merata dan sebagian sarjana ternyata menganggur. Indonesia gagap menanggapi globalisasi. Para aktivis mahasiswa yang saat itu berjuang kini telah memilih jalan hidupnya masing masing. Tantangan ke depan adalah bagaimana mengembangkan karakter, menghormati keberagaman, dan menumbuhkan sikap nasionalis bagi kaum muda sehingga mereka dapat berperan sebagai katalis perubahan. Beberapa buku dan film telah ada yang membahas tentang 
persitiwa reformasi 98 dari berbagai sudut padang, tetapi belum pernah ada yang melakukan dalam bentuk rekaman yang berkesinambungan. Penelitian yang dilakukan merupakan kelanjutan dari rekaman visual para aktivis yang tergabung dalam Front Aksi Mahasiswa untuk Reformasi dan Demokrasi (Famred) pada tahun 98. Berdasarkan dokumentasi tahun 98 kemudian dilacak kembali beberapa pimpinan mahasiswa tersebut dan dilakukan wawancara dan serta pemotretan yang hasilnya dipamerakan pada tahun 2008 dengan judul "10 Years Later". Saat ini, menjelang peringatan 20 tahun reformasi, penulis kembali melanjutkan proses dokumentasi mereka sebagai persiapan pameran pada tahun 2018.

Barthes mengatakan, fotografi adalah ingatan kolektif dunia (Barthes, 2000). Manusia adalah subyek paling umum dalam fotografi. Foto potret seseorang paling mudah untuk dikenali dan bercerita tentang sesuatu. Foto potret telah dikenal sejak awal sejarah fotografi dan tetap bertahan sampai sekarang. Foto potret berbeda dengan "human interest" dan "fashion", meskipun menampilkan subyek yang sama. Foto potret bersifat pribadi. Foto potret bertujuan untuk menampilkan kepribadian dan karakteristik seseorang (Burnside, 1900). Fotografi merekam suatu peristiwa yang abadi menjadi sesuatuyangabadi. Foto sebagai perekam waktu, mengeluarkan obyeknya keluar dari sejarah. Setiap foto tidak memiliki masa depan dan masa lalu, ia hanya merekam saat ini. (Clark, 1997, p.24).

Foto sebagai teks dapat dianalisis melalui pendekatan semiotik yang awalnya berasal dari bidang bahasa (linguistic), diperkenalkan oleh Ferdinand de Saussure. Semiotic strukturalis (Eropa) fokus pada mencari relavansi dan makna dari suatu tanda, berkaitan dengan konteks sosial budaya. Adapun Charles Sanders Peirce (Amerika) seorang pendiri pragmatism mengembangkan analisis semiotic yang berbeda, yaitu pada produksi makna, menekankan aspek hasil - dampak dari tanda yang dihasilkan. (Sobur, 2009, p. 40-41). Peirce membagi tanda (sign) menjadi 3 bagian, yaitu : (1) representament - tanda; (2) object - sesuatu yang dirujuk ; (3) interpretant - hasil hubungan representament dengan object. Pada level object, Peirce juga memperkenalkan istilah (1) icon - hubungan antara tanda dan objek berdasarkan kemiripan; (2) index - hubungan sebab akibat; (3)symbol - hubungan antara tanda 
dan penandanya berdasarkan konvensi masyarakat. (Vera, 2014, p.22 - 25)

Fotografi dapat dikategorikan sebagi seni visual, sebagai medium untuk menampilkan suatu obyek, ide/gagasan. Dari aspek penciptaannya, seni adalah pengejawantahan salah satu dari berbagai potensi virtual yang dikembangkan dari pengamatan yang mendalam atas suatu objek atau subjek. Proses kreatif seni adalah suatu lompatan dari yang imaterial menjadi sesuatu yang termaterialisasi. (Marianto, 2017, p.62)

\section{METODE}

Penelitian ini bersifat kualitatif dan menggunakan pendekatan metodologi visual. Tujuan penelitian adalah menggambarkan karakteristik agen perubahan dalam tampilan vsiual berupa foto potret mereka. Berdasarkan buku Visual Methodologies penggunaan gambar dalam menjawab pertanyaan penelitian bukan hanya sebagai obyek kajian tetapi bisa pula dengan membuat gambar sebagai bagian ataupun pendukung penelitian (Rose, 2007, p.6). Peneliti melakukan studi pendahuluan terhadap subyek penelitian, kemudian membuat konsep foto potret. Subyek adalah partisipan yang dipilih dengan metode purposive sampling, yaitu subyek yang dipilih berdasarkan kriteria bahwa mereka para perwakilan (pemimpin) mahasiswa yang berasal dari berbagai kampus di Jakarta, tergabung dalam gerakan mahasiswa Front Aksi Mahasiswa untuk Reformasi dan Demokrasi (Famred). Ada 30 orang yang telah difoto dan wawancara dan untuk keperluan tulisan ini maka dipilih sepuluh nama yang dianggap dapat mewakili mereka dan ada foto mereka tahun 1998 atau 2008.

Setting penelitian ini dilakukan di daerah Jakarta. Instrumen penelitian yang digunakan adalah: alat perekam gambar dan suara, peralatan tulis/ perlengkapan lainnya. Waktu penelitian dan pemotretan adalah bulan Februari, Maret, dan April 2017. Berdasarkan pemahaman atas subyek maka kemudian dibuatlah foto konsep melalui analisis semiotik pragmatik Charles Sanders Peirce. Hasil penelitian adalah foto potret agen perubahan sebagai bagian dari kegiatan persiapan memperingati duapuluh tahun reformasi 98. Dokumentasi berupa foto dan video wawancara bukan hanya berperan sebagai pendukung tetapi sebagai media komunikasi visual yang berperan dalam menyebarkan ide, gagasan, dan cerita tentang para agen perubahan kepada masyarakat luas, khususnya generasi muda. 
Penelitian yang dilakukan merupakan hibah DIKTI dengan menggunakan skema penelitian produk terapan untuk tahun 2017 - 2018 dengan judul "Karakteristik Agen Perubahan untuk Menciptakan Tatanan Masyarakat yang Lebih Baik." Adapun melalui tulisan ini dibahas aspek fotografi pada penelitian yang dilakukan.

\section{HASIL DAN PEMBAHASAN}

Hasil pembahasan diuraikan dalam 2 kategori. Pertama adalah analisis semiotik berdasarkan triadik Charles Sanders Peirce, untuk membuat konsep foto potret. Kedua adalah hasil pemotretan para aktivis sebagai perwujudan dari ide/ konsep.

\section{A. Tabel}

Tabel 1 : Tabel Analisa Semiotik Charles Sanders Peirce terhadap Agen Perubahan

\begin{tabular}{|c|c|c|c|}
\hline & $\begin{array}{l}\text { Representament } \\
\text { (Sign) }\end{array}$ & Object & Interprentant \\
\hline 1 & $\begin{array}{l}\text { Foto Benny Hari } \\
\text { Juliawan. SJ. } \\
\text { Koordinator } \\
\text { Karya Sosial } \\
\text { Jesuit Se-Asia } \\
\text { Tenggara } \\
\text { Rohaniwan, } \\
\text { pemerhati buruh } \\
\text { migran }\end{array}$ & $\begin{array}{l}\text { Pose berdiri } \\
\text {, tersenyum } \\
\text { menatap } \\
\text { kamera } \\
\text { Background } \\
\text { slogan; "Be } \\
\text { Honest" } \\
\text { di lapangan } \\
\text { sepak bola }\end{array}$ & $\begin{array}{l}\text { Menampilkan } \\
\text { orang muda } \\
\text { yang percaya } \\
\text { diri , relaks dan } \\
\text { berpegang } \\
\text { pada nilai - } \\
\text { nilai kejujuran }\end{array}$ \\
\hline 2 & $\begin{array}{l}\text { Foto Bona } \\
\text { Sigalingging } \\
\text { Aktivis } \\
\text { kebebasan } \\
\text { beragama dan } \\
\text { beribadat } \\
\text { Koord Program } \\
\text { ILO }\end{array}$ & $\begin{array}{l}\text { Pose duduk, } \\
\text { tersenyum } \\
\text { menatap } \\
\text { kamera, } \\
\text { memegang } \\
\text { buku } \\
\text { "confession } \\
\text { " }\end{array}$ & $\begin{array}{l}\text { Menampilkan } \\
\text { seorang } \\
\text { intelektual } \\
\text { muda yang } \\
\text { idealis }\end{array}$ \\
\hline 3 & Foto Savic Ali & $\begin{array}{l}\text { Pose duduk, } \\
\text { tersenyum } \\
\text { menantap }\end{array}$ & $\begin{array}{l}\text { Menampilkan } \\
\text { sosok yang } \\
\text { independen, }\end{array}$ \\
\hline
\end{tabular}

\begin{tabular}{|c|c|c|c|}
\hline & $\begin{array}{l}\text { Pendiri, direktur } \\
\text { NU Onlie, NU } \\
\text { tizen }\end{array}$ & $\begin{array}{l}\text { kamera, } \\
\text { berkaos } \\
\text { oblong biru. } \\
\text { Latar } \\
\text { belakang } \\
\text { kaca yang } \\
\text { penuh } \\
\text { coretan } \\
\text { spidol }\end{array}$ & $\begin{array}{l}\text { kreatif dan } \\
\text { berjiwa bebas } \\
\text { (free thinker) }\end{array}$ \\
\hline 4 & $\begin{array}{l}\text { Foto Komala Sari } \\
\text { Executive } \\
\text { Assistant for the } \\
\text { CEO }\end{array}$ & $\begin{array}{l}\text { Pose duduk, } \\
\text { tersenyum } \\
\text { menatap } \\
\text { kamera, } \\
\text { mengenakan } \\
\text { blazer biru } \\
\text { gelap dalam } \\
\text { ruang rapat } \\
\text { di kantor }\end{array}$ & $\begin{array}{l}\text { Menampilkan } \\
\text { seorang wanita } \\
\text { profesional } \\
\text { yang mandiri }\end{array}$ \\
\hline 5 & $\begin{array}{l}\text { Foto Ulung } \\
\text { Rusman } \\
\text { Wakil Sekjen } \\
\text { Perhimpunan } \\
\text { INTI } \\
\text { Dept Pemuda } \\
\text { Partai Nasional } \\
\text { Demokrat }\end{array}$ & $\begin{array}{l}\text { Pose duduk, } \\
\text { tersenyum } \\
\text { menatap } \\
\text { kamera, } \\
\text { berbaju } \\
\text { putih } \\
\text { organisasi. } \\
\text { Latar } \\
\text { belakang } \\
\text { bendera } \\
\text { organisasi } \\
\text { berwarna } \\
\text { merah putih }\end{array}$ & $\begin{array}{l}\text { Menampilkan } \\
\text { seorang muda } \\
\text { organisasi } \\
\text { Tionghoa yang } \\
\text { nasionalis }\end{array}$ \\
\hline 6 & $\begin{array}{l}\text { Foto Arif Rahman } \\
\text { Staf Khusus } \\
\text { Menteri } \\
\text { Pertahanan }\end{array}$ & $\begin{array}{l}\text { Pose berdiri } \\
\text { dengan satu } \\
\text { kaki } \\
\text { terangkat, } \\
\text { tersenyum } \\
\text { nenatap } \\
\text { kamera. } \\
\text { Berbaju } \\
\text { batik merah } \\
\text { dengan } \\
\text { background } \\
\text { pagar } \\
\text { berlambang } \\
\text { kementrian } \\
\text { pertahanan } \\
\text { nasional }\end{array}$ & $\begin{array}{l}\text { Menampilkan } \\
\text { sosok yang } \\
\text { berani, } \\
\text { percaya diri, } \\
\text { berkecimpung } \\
\text { di bidang } \\
\text { politik } \\
\text { pemerintahan }\end{array}$ \\
\hline 7 & $\begin{array}{l}\text { Foto Masinton } \\
\text { Pararibu } \\
\text { Anggota Komisi } \\
\text { III DPR RO, PDIP, } \\
\text { Ketua Umum } \\
\text { Repdem }\end{array}$ & $\begin{array}{l}\text { Pose berdiri } \\
\text { merentangk } \\
\text { an kaki dan } \\
\text { bertolak } \\
\text { pinggang, } \\
\text { wajah } \\
\text { tersenyum } \\
\text { menghadap } \\
\text { kamera, } \\
\text { background } \\
\text { gedung DPR }\end{array}$ & $\begin{array}{l}\text { Menampilkan } \\
\text { sosok yang } \\
\text { kuat, } \\
\text { menantang, } \\
\text { berkecimpung } \\
\text { dalam dunia } \\
\text { politik praktis } \\
\text { sebagai wakil } \\
\text { rakyat. }\end{array}$ \\
\hline
\end{tabular}




\begin{tabular}{|c|c|c|c|}
\hline 8 & $\begin{array}{l}\text { Foto Wahab } \\
\text { Talaohu } \\
\text { Bidang } \\
\text { Organisasi Partai } \\
\text { Hanura }\end{array}$ & $\begin{array}{l}\text { Pose duduk, } \\
\text { memegang } \\
\text { kertas, } \\
\text { tersenyum } \\
\text { mennatao } \\
\text { kamera, } \\
\text { mengenakan } \\
\text { seragam } \\
\text { partai }\end{array}$ & $\begin{array}{l}\text { Menampilkan } \\
\text { sosok yang } \\
\text { intelektual } \\
\text { bersemangat } \\
\text { berkecimpung } \\
\text { dalam bidang } \\
\text { politik praktis }\end{array}$ \\
\hline 9 & $\begin{array}{l}\text { Foto Dwinanto } \\
\text { Marketing } \\
\text { Manager Foto }\end{array}$ & $\begin{array}{l}\text { Pose berdiri } \\
\text { tersenyum } \\
\text { menatap } \\
\text { kamera, } \\
\text { mengenakan } \\
\text { jas dan dasi } \\
\text { dengan } \\
\text { background } \\
\text { buku - buku }\end{array}$ & $\begin{array}{l}\text { Menampilkan } \\
\text { sosok } \\
\text { profesional di } \\
\text { bidang bisnis } \\
\text { penjualan } \\
\text { buku }\end{array}$ \\
\hline 10 & $\begin{array}{l}\text { Riki Dior } \\
\text { Street } \\
\text { Photographer, } \\
\text { founder } \\
\text { Indonesia on the } \\
\text { Street }\end{array}$ & $\begin{array}{l}\text { Pose berdiri, } \\
\text { tersenyum } \\
\text { menatap } \\
\text { kamera, } \\
\text { mengenakan } \\
\text { kemeja blue } \\
\text { jeans, } \\
\text { membawa } \\
\text { kamera di } \\
\text { pinggir jalan } \\
\text { raya }\end{array}$ & $\begin{array}{l}\text { Menampilkan } \\
\text { seorang yang } \\
\text { bebas, } \\
\text { menjalani } \\
\text { hidup sesuai } \\
\text { "passion" di } \\
\text { bidang } \\
\text { fotografi }\end{array}$ \\
\hline
\end{tabular}

Pendekatan genre fotografi yang digunakan adalah foto potret, untuk menampilkan sosok, karakter dari agen perubahan yang dipilih. Pose yang dipilih adalah wajah yang menghadap dan menatap kamera sambil tersenyum, untuk menampilkan rasa percaya diri, mandiri serta sikap terbuka dan ramah). Foto potret yang dibuat merupakan icon dari subyek (agen perubahan).
Atribut (pakaian/ perlengkapan/ benda) merupakan symbol, berupa; setting (lokasi/ tata ruang) yang digunakan berbeda - beda disesuaikan dengan konteks aktivitas dan bidang kerja mereka saat ini, serta berdasarkan hasil wawancara yang dilakukan, misalnya saja ada nilai - nilai hidup yang diperjuangkan atau ada buku atau sesuatu yang menginspirasi mereka.

\section{B. Gambar}

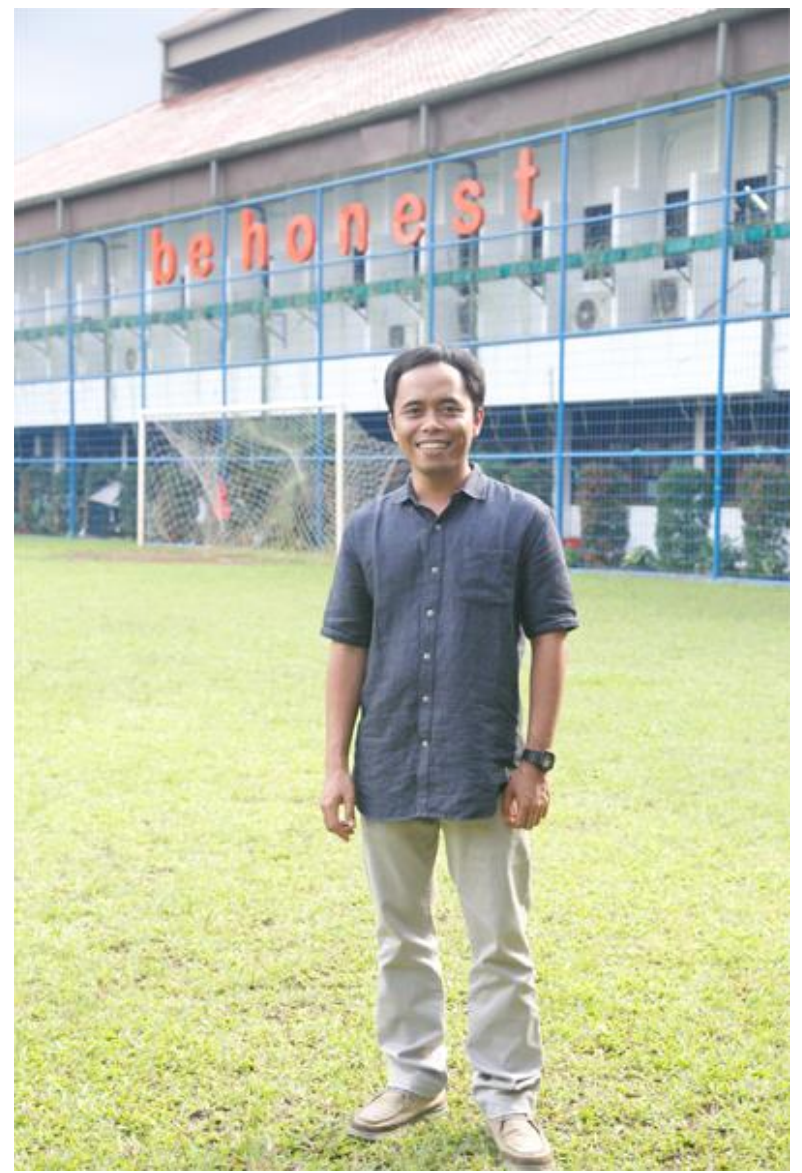

Gambar 1. Foto Benny Hari Julianto, SJ., 2017 


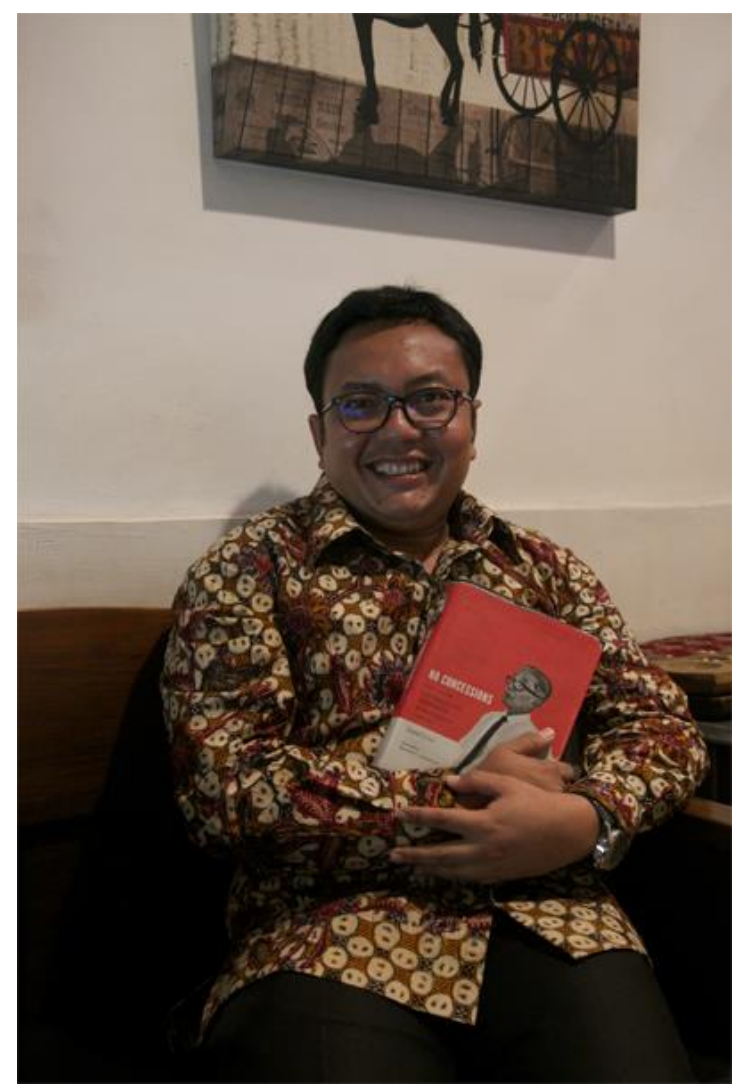

Gambar 2. Foto Bona Sigalingging, 2017

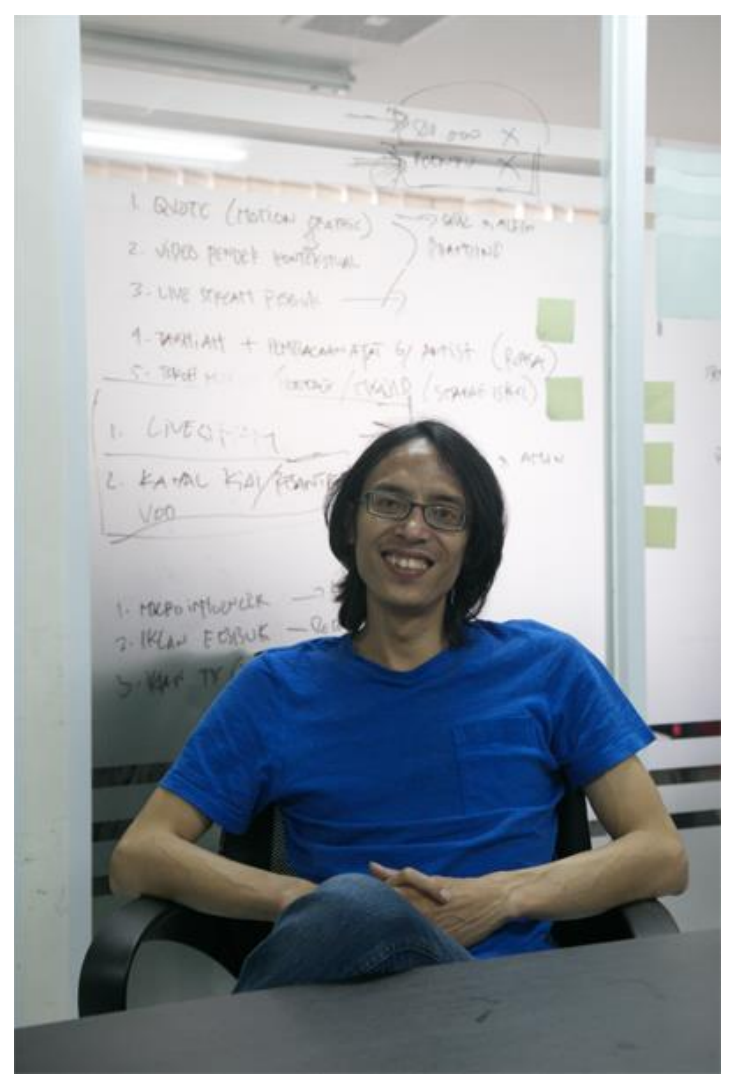

Gambar 3. Foto Savic Ali, 2017

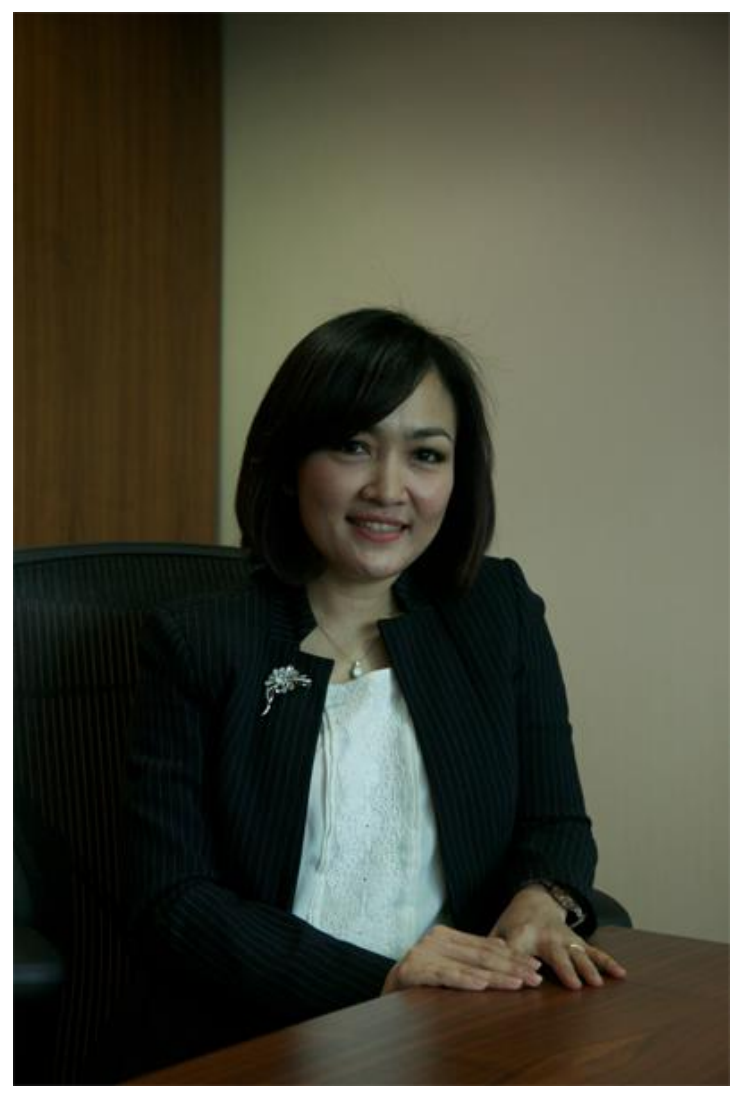

Gambar 4. Foto Komala Sari, 2017

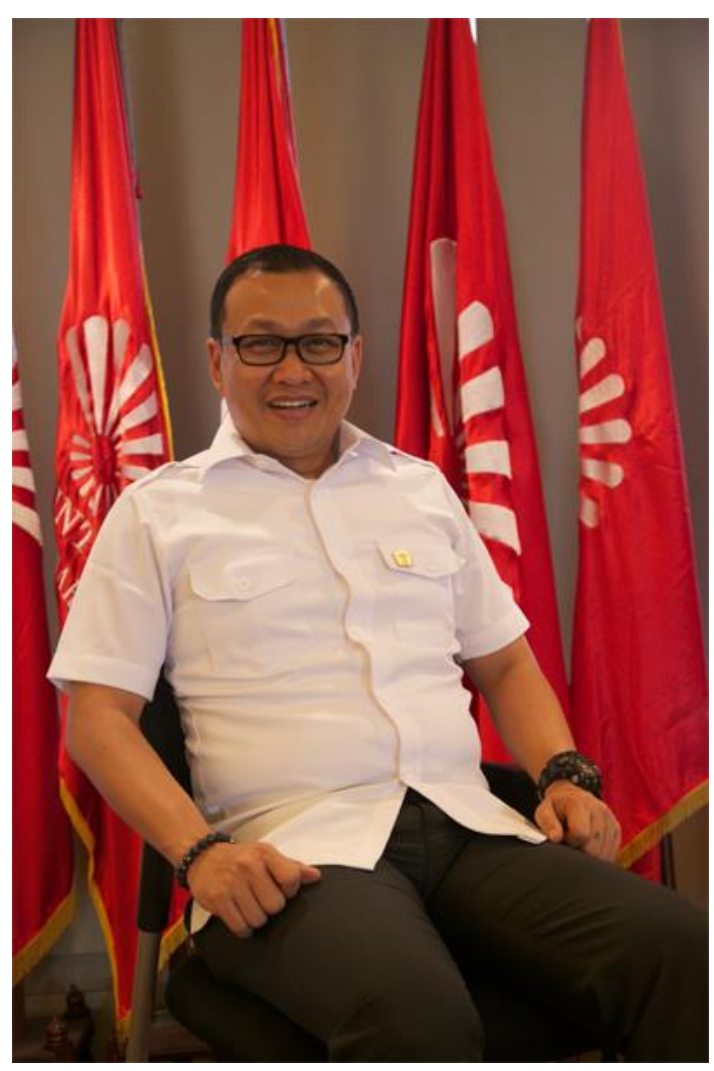

Gambar 5. Foto Ulung Rusman, 2017 


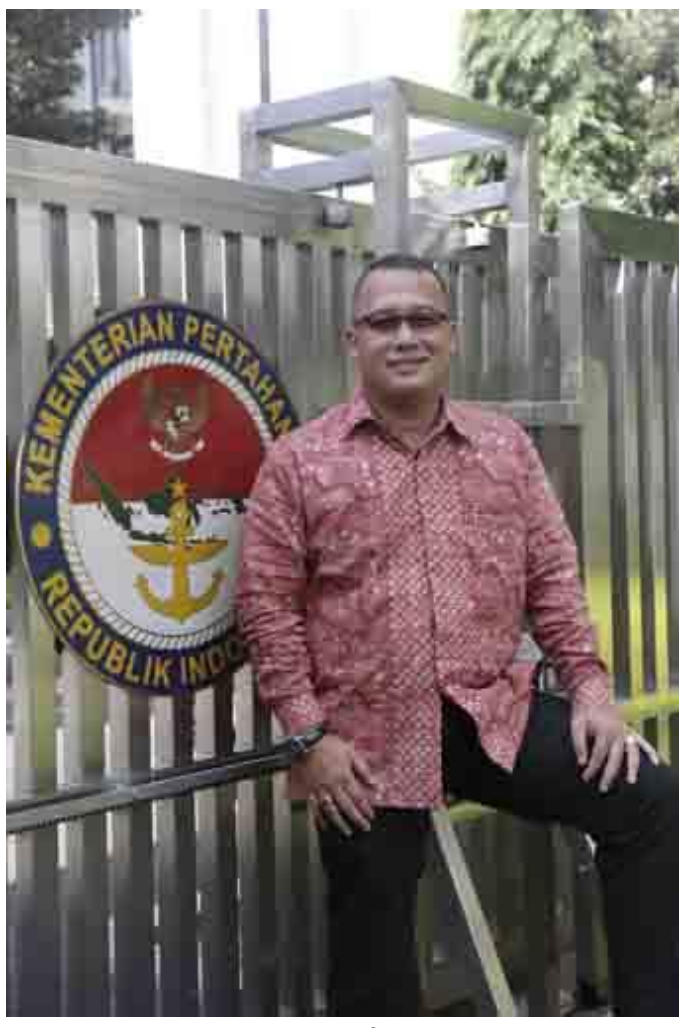

Gambar 6. Foto Arif Rahman, 2017

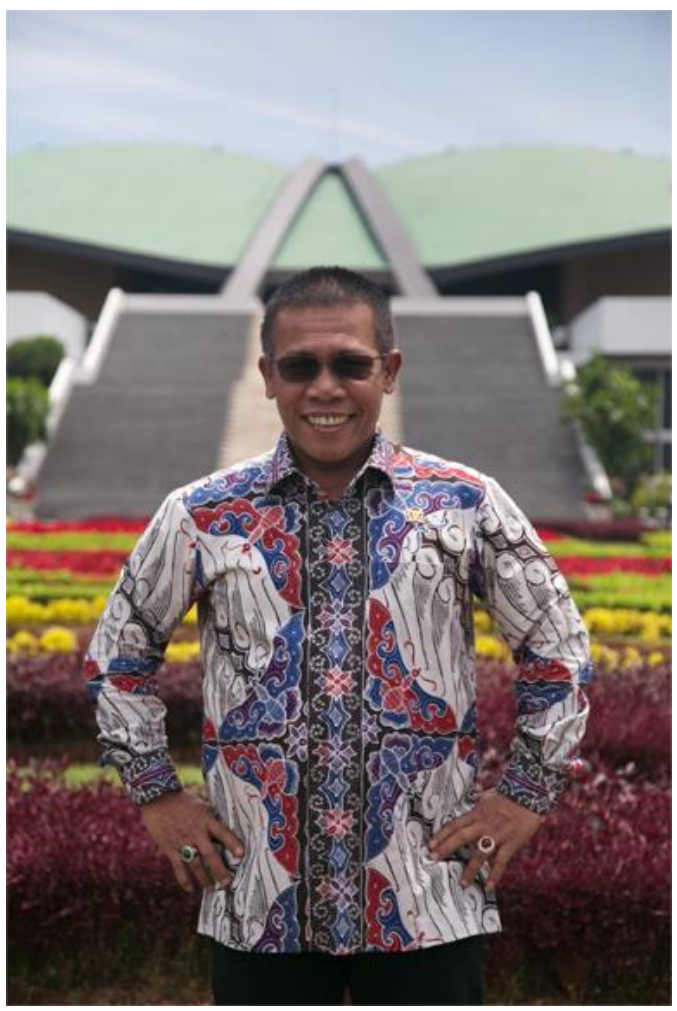

Gambar 7. Foto Masinton Pasaribu, 2017

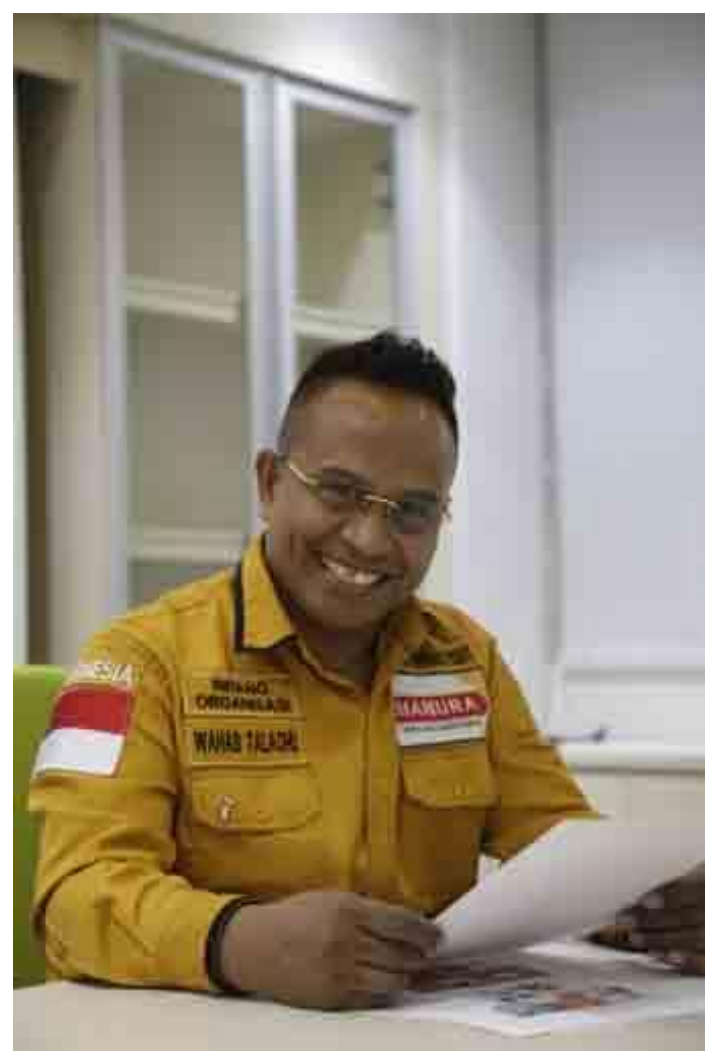

Gambar 8. Foto Wahab Talaohu, 2017

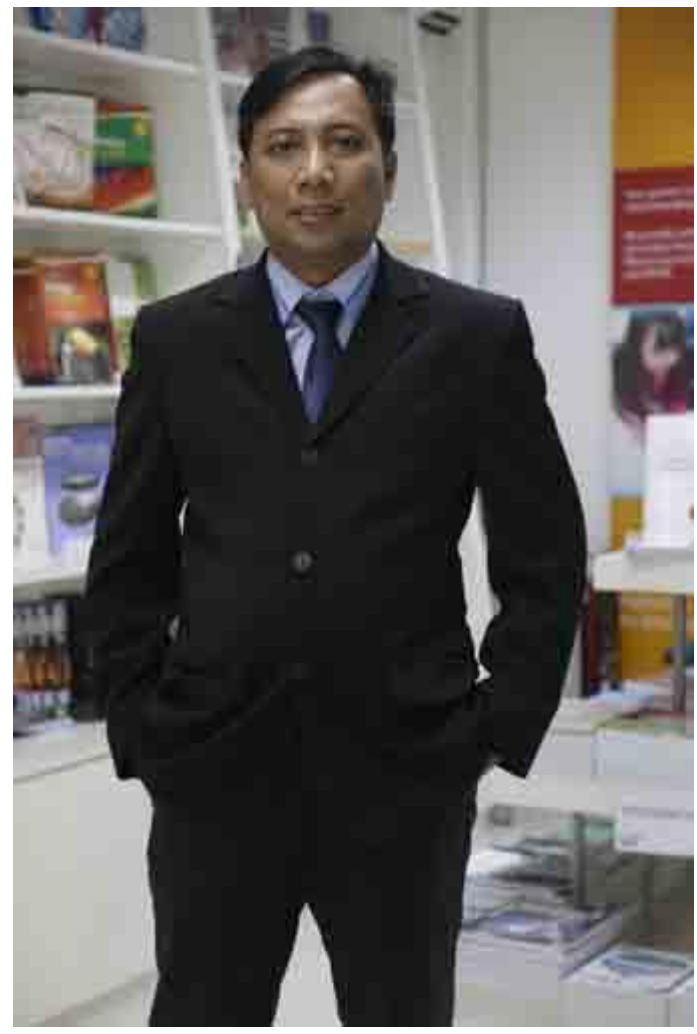

Gambar 9. Foto Dwinanto, 2017 


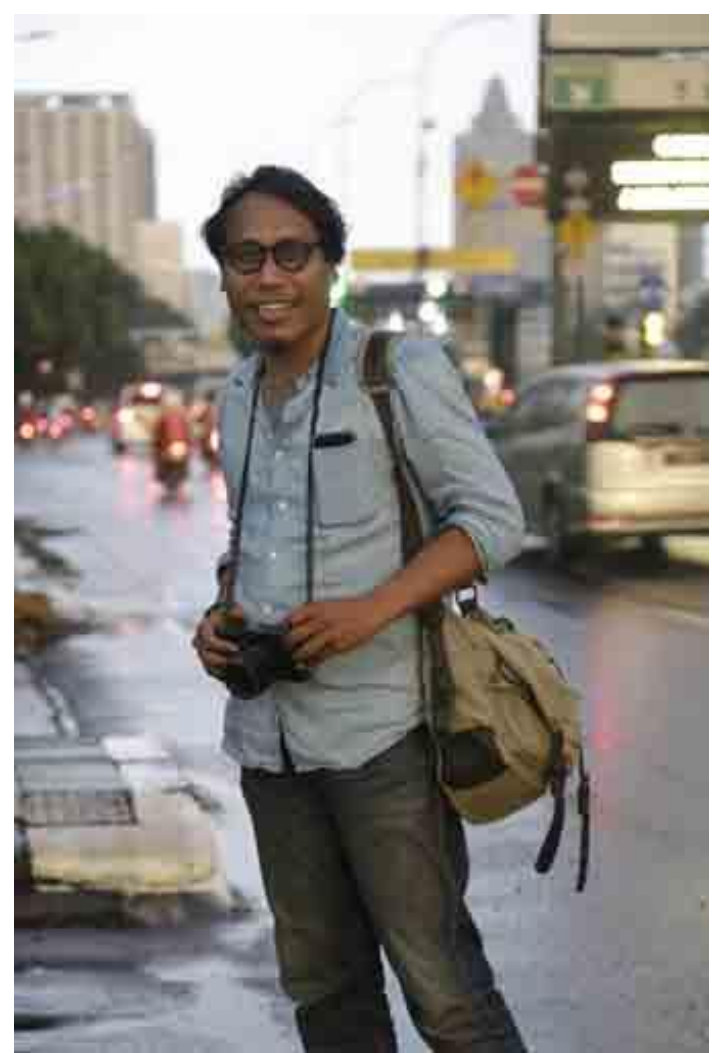

Gambar 9. Foto Riki Dior, 2017

\section{SIMPULAN}

Pendekatan semiotik Charles Sanders Peirce (aliran pragmatik, biasa dipakai untuk memproduksi makna) sengaja dipilih untuk membantu peneliti dalam membuat konsep foto sehingga dapat menampilkan karakter para agen perubahan yang bermakna. Perlu dilakukan pengenalan subyek/ studi pendahuluan tentang siapa mereka dan perlu melakukan wawancara untuk menggali sifat, nilai - nilai, pengalaman, dan keunikan (kekhasan) mereka.

Foto potret agen perubahan sebagai subyek penelitian merupakan icon (yang menampilkan kemiripan dengan subyek dalam bentuk media foto). Atribut (pakaian/ benda/ perlengkapan), setting (lokasi dan tata ruang) merupakan symbol yang dipakai sebagai pertimbangan untuk mendukung pemotretan dan memunculkan karakter mereka dengan optimal.

Penelitian ini masih dapat dan perlu dilanjutkan sehubungan dengan kelengkapan analisis dari aspek / konteks sosial, politik, dan budaya. Para agen perubahan yang diangkat melalui tulisan ini dapat ditambah jumlahnya, sehingga dapat lebih banyak jumlahnya untuk kajian selanjutnya.

\section{UCAPAN TERIMA KASIH}

Penulis mengucapkan terima kasih atas dukungan semua pihak yang telah mmembantu, kepada Fakultas Seni Rupa dan Desain, kepada tim peneliti dan para sahabat agen perubahan yang terlibat sebagai partisipan.

\section{DAFTAR PUSTAKA}

Alex Sobur. 2009. Semiotika Komunikasi. Bandung : PT Remaja Rosdakarya.

Barthes, Roland. 2000.Camera Lucida. London: Vintage.

Burnside, Maud. 1900. Artistic Photography in Portraiture. Brush and Pencil. Vol 6. No.3. pp $122-125,127$. 
Clarke, Graham. 1997. The Photograph.

New York: Oxford University Press.

Dwi Marianto, 2017. Art \& Life Force in

Quantum Perspective. Scritto Books

Publisher.

Lane, Max. 2014. Unfinished Nation.

Yogyakarta : Djaman Baroe.

Nawiroh Vera. 2014. Semiotika dalam Riset

Komunikasi. Bogor : Ghalia Indonesia.

Rose, Gillian. 2007. Visual Methodologies.

London : Sage Publication. 


\title{
Evaluasi terhadap Konsep Desain Interior Ramah Lingkungan pada Lobby Lounge Boutique Hotel
}

\author{
Studi Kasus : Greenhost Boutique Hotel Yogyakarta
}

Fivanda

Universitas Tarumanagara

fivanda@fsrd.untar.ac.id

\begin{abstract}
Konsep desain yang beberapa tahun belakangan ini dikembangkan oleh desainer, arsitek dan pengusaha hotel umumnya mengedepankan konsep ramah lingkungan. Dibalik beberapa kesuksesan perkembangan hotel masa kini, konsumen memang lebih menggemari konsep desain hotel yang berhubungan dengan alam dan terkesan alami. Konsep ramah lingkungan sebagai salah satu wujud implementasi konsep pembangunan berkelanjutan dan merupakan salah satu langkah bagi masyarakat untuk ikut serta terhadap kepedulian lingkungannya. Konsep ramah lingkungan sekarang sudah mulai diterapkan pada hotel dari mulai budget hotel hingga boutique hotel. Greenhost boutique hotel Yogyakarta ini mengedepankan konsep ramah lingkungan pada keseluruhan interior, bangunan dan manajemennya. Konsep Sustainable (berkelanjutan) ini ditandai dengan adanya kestabilan, dimana perubahan-perubahan terus dibatasi untuk menjaga keseimbangan dari sistem pada masa depan. Ada tiga hal yang menjadi tujuan dari konsep yang sudah dicapai yaitu meminimalkan konsumsi bahan dan energi, mencegah efek negatif pada daya dukung lingkaran dan lingkungan itu sendiri serta memenuhi kebutuhan manusia. Adanya keseimbangan yang harmonis antara manusia sebagai pengguna dengan kebiasaan manusia serta lingkungan sehingga di masa depan dapat dicapai kesinambungan dan keseimbangan hidup. Selain itu, Konsep sustainable tidak hanya diterapkan pada peletakan pintu utama, bukaan alami jendela, pencahayaan alami tetapi juga terhadap furnitur dan material yang digunakan menghasilkan limbah daur ulang yang ramah lingkungan.
\end{abstract}

Kata Kunci : hotel, boutique hotel, konsep desain, sustainable design.

\section{PENDAHULUAN}

Perkembangan IImu dan Teknologi yang sangat pesat sekarang ini seringkali menimbulkan banyak dampak negatif terhadap lingkungan. Pembangunan mempengaruhi dan dipengaruhi oleh lingkungan sekitarnya. Prinsip-prinsip penghijauan pada fasilitas ruang publik perlu diterapkan dari sisi pemahaman konsep sustainable. Beberapa pendekatan konsep penghijauan dan berkelanjutan dalam bangunan publik (Tri Harso Karyono, 2013) yaitu dengan meminimalkan perolehan panas (heat gain) dari radiasi matahari pada bangunan seperti membuat dinding lapis berongga yang diberi ventilasi pada rongganya dan membuat ventilasi pada ruang antara atap dan langit-langit agar tidak terjadi akumulasi panas, serta memaksimalkan pelepasan panas dalam bangunan. Dalam perancangan konsep ruang publik perlu mempertimbangkan kenyamanan fisik dan kenyamanan termal serta memiliki ruang terbuka hijau pada lingkungan sekeliling untuk meningkatkan aliran udara. Prinsip penghijauan pada 
beberapa kota di Indonesia tampaknya sudah mulai diterapkan.

Seiring peningkatan jumlah wisatawan yang datang, kebutuhan pada akomodasi hotel yang merupakan tempat para wisatawan beristirahat pun ikut meningkat. Pilihan jenis hotel masa kini pun semakin banyak, yang diantaranya adalah boutique hotel. Boutique hotel menawarkan harga terjangkau dengan kenyamanan dan konsep desain yang unik. Berdasarkan pengamatan, pada umumnya boutique hotel memasukkan karakter tertentu dari suatu daerah tempatnya dibangun. Peningkatan jumlah wisatawan lebih memilih mendapatkan pengalaman baru dengan memilih hotel butik yang memiliki daya tarik tersendiri. Akan dapat menjadi daya tarik baru untuk wisatawan yang datang Yogyakarta terutama pelaku desain dan seni.

Boutique hotel pada dasarnya tidak mempunyai standarisasi minimum jumlah dan ukuran kamarnya. Hotel boutique menargetkan beberapa kota-kota yang menjadi destinasi wisata. Di Indonesia sendiri hotel boutique banyak ditemukan di Surakarta, Yogyakarta, Bali dan Bandung. Desainnya dibuat lekat dengan unsure budaya masyarakat setempat. Prinsip-prinsip hotel boutique pada umumnya (Lawson : 1999) :

- Penggunaan elemen-elemen perancangan yang tidak biasa seperti garis, warna, bentuk, tekstur, pola, ruang dan cahaya.

- Langgam arsitektur yang berbeda dari lingkungan di sekitarnya.

- Hotel berskala kecil yang memiliki gaya dan ciri khas tersendiri.

- Fokus terhadap gaya yang eksotis, keramahan dari keakraban serta pelayanan yang memuaskan.

- Unsur Teknologi pembangunan seperti konsep ecodesign juga sudah berkembang pada pembangunan hotel boutique sekarang ini.

Greenhost Hotel didirikan di Yogyakarta pada tahun 2014 oleh Paulus Mintarga, Ananda Soewono, serta Santo. Sejak awal Greenhost Hotel telah berkomitmen untuk keberlangsungan dan berkewajiban terhadap lingkungan dan masyarakat sekitar. Greenhost Boutique Hotel merupakan hotel boutique pertama yang ramah lingkungan di Indonesia dengan menawarkan fasilitas modern dengan sentuhan budaya lokal di lingkungan yang tenang dan ramah. 
Greenhost Hotel merupakan boutique hotel dengan konsep dan tempat yang dinamis. Konsep penggabungan perhotelan yang santai dengan pengalaman yang kreatif dalam bidang desain, seni, kerajinan dan kota pertanian Yogyakarta. Mengaplikasikan konsep sustainable dengan berbagai cara, sehingga memiliki gayanya tersendiri yang menjadi daya tarik hotel ini. Konsep Sustainable itu sendiri salah satunya diartikan oleh World Commision on Environment and Development tahun 1987 sebagai : "Pemenuhan kebutuhan pada saat sekarang tanpa merugikan generasi masa depan untuk memenuhi kebutuhan mereka". Konsep boutique hotel yang berkembang saat ini merupakan gagasan yang memadukan berbagai unsur kedalam suatu kesatuan. Unsur - unsur dari konsep ini dapat berupa gagasan, pendapat dan pengamatan. Konsep Sustainable (berkelanjutan) Greenhost Hotel ini lebih kepada tata letak layout bangunan, interior dan material furniture yang diterapkan. Dengan sebuah sistem yang ditandai dengan kestabilan, dimana perubahan-perubahan terus dibatasi untuk menjaga keseimbangan dari sistem pada masa depan. Dari gabungan semua konsep dasar dalam interior ada 3 hal yang menjadi tujuan konsep sustainable dasar yang ingin dicapai (Jong-Jin Kim : 1998) :

1. Meminimalkan konsumsi bahan dan energi.

2. Mencegah efek negatif pada daya dukung lingkaran dan lingkungan itu sendiri.

3. Memenuhi kebutuhan manusia.

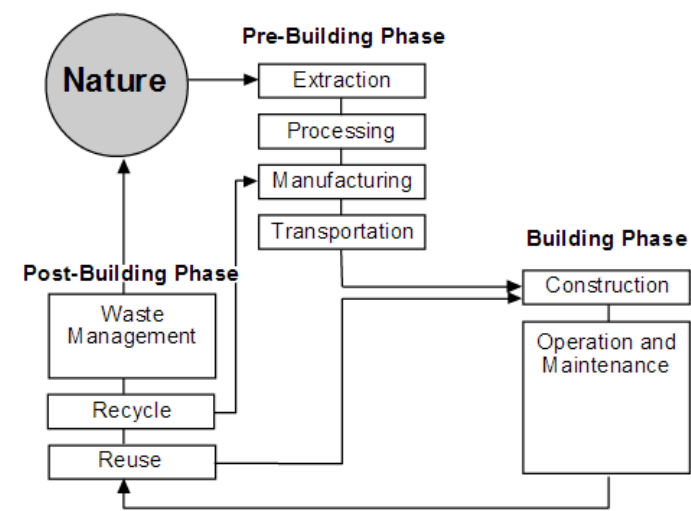

Gambar 1. The Sustainable Building Life Cycle (Jong-Jin Kim. Brend Rigdon. Sustainable Architecture Module : Introduction to Sustainable, 1998)

Konsep material ramah lingkungan memiliki kriteria :

1. Tidak beracun sebelum maupun sesudah digunakan.

2. Dalam proses pembuatannya tidak memproduksi zat-zat berbahaya bagi lingkungan.

3. Dapat menghubungkan manusia dengan alam, dalam arti pengguna semakin dekat dengan alam karena kesan alami dari material tersebut. 
4. Bisa didapatkan dengan mudah dan dekat (tidak memerlukan ongkos atau proses memindahkan yang besar, karena menghemat energi BBM untuk memindahkan material tersebut ke lokasi pembangunan).

5. Dapat terurai dengan mudah secara alami.

6. Mengandung prinsip Renewable, Reuse, Recycle, \& Reduce.

Melalui pertimbangan cermat pada dampaknya, bahwa sistem pengoprasian, material dan kebijakan terhadap lingkungan, hotel ini terus mengembangkan inisiatif dan prosedur baru untuk meminimalkan dampak ekologi dalam kelangsungan hidup manusia sebagai pengguna.

\section{METODE}

Penelitian ini mengambil objek penelitian yaitu Greenhost Boutique Hotel Prawirotaman, Yogyakarta dengan area penelitian mencakup tata layout bangunan dan interior diantaranya ruang lobby, area lobby lounge dan area restoran Art-Kitchen. Penelitian ini menggunakan teknik observasi dengan pengamatan langsung pada ketiga ruang dan area tersebut. Kemudian mendokumentasikan data visual berupa foto mengenai permasalahan yang sedang diteliti. Teknik observasi ini menghasilkan gambaran konkret mengenai aplikasi konsep sustainable dan penerapan konsep sustainable pada bahan material arsitektur serta interior.

Setelah proses pengambilan data dan observasi dilakukan, dilanjutkan pada tahapan analisa evaluasi kondisi interior dengan parameter material dan tata letak layout interior yang ramah lingkungan dengan pendukung studi literature. Teknik studi literatur ini digunakan untuk memperoleh landasan teori dan informasi yang dibutuhkan oleh peneliti.

\section{HASIL DAN PEMBAHASAN}

Lobby Lounge Greenhost

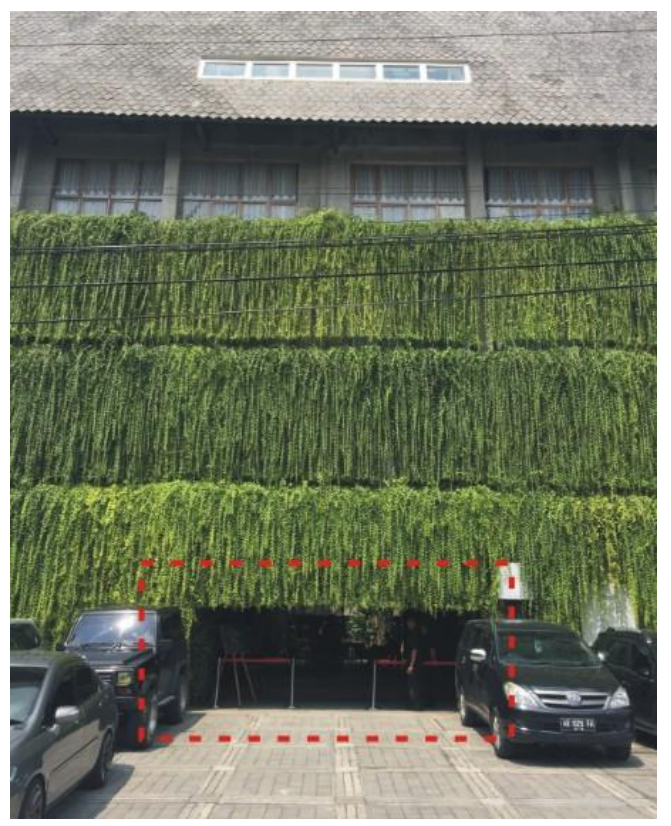

Gambar 2. Area Masuk ke Lobby dari Fasade Bangunan (Dokumentasi Pribadi, 2017) 
Area Lobby merupakan area publik yang menjadi ruangan pertama yang dimasuki oleh pengunjung. Area masuk lobby hotel Greenhost terletak di bagian depan tengah bangunan seperti terlihat pada Gambar 2

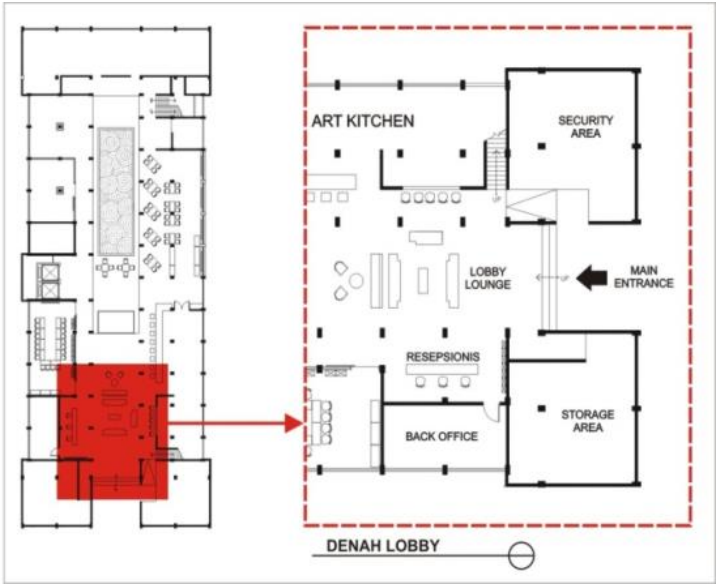

Gambar 3. Denah Lantai Dasar Area Lobby (Data Pribadi, 2017)

dan Gambar 3 area masuk ini merupakan area bukaan yang besar tanpa pintu dari fasade bangunan.

Pengunjung masuk melalui area tengah bangunan menuju lobby lounge yang terdiri dari kursi dengan material kayu dan besi. Di area tengah tersebut terdapat patung seorang anak kecil dengan tangan yang bertransformasi menjadi tanaman yang dihinggapi burung yang terbuat dari besi. Artwork patung ini menjadi icon utama di lobby yang menjadi ciri khas hotel Greenhost seperti terlihat pada Gambar 4.

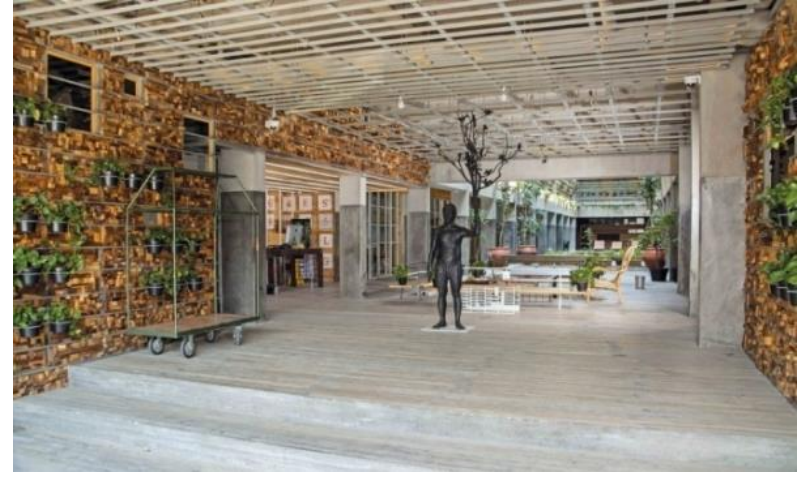

Gambar 4. Patung besi (Artwork Patung) pada area masuk Lobby Lounge

(Greenhost Hotel, 2017)

Ruangan kiri dan kanan pada area masuk merupakan ruangan privasi untuk security dan ruang penyimpanan untuk pengelola serta karyawan, sehingga dinding dibuat tertutup dengan partisi dan juga material olahan panel kayu jati sisa dengan rangka besi seperti pada Gambar 4 dan Gambar 5. Selain itu dinding partisi juga ditambahkan unsur tanaman yang digantung menggunakan besi sehingga memperkuat kesan alami dan ramah lingkungan.

Material lantai menggunakan beton ekspos dengan pola dan serat menyerupai kayu, sedangkan ceiling ekspos beton ditambahkan unsur rangka besi sebagai penguat aksen ruangan juga berfungsi sebagai penempatan pencahayaan tidak langsung (indirect) untuk pencahayaan umum buatan pada malam hari Gambar 5 . 


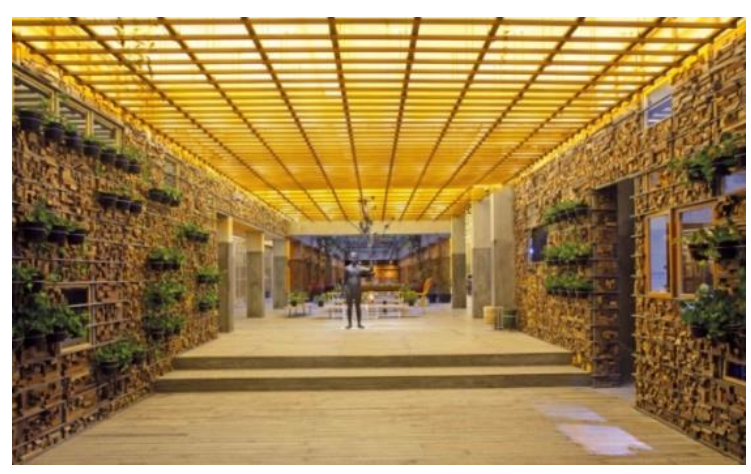

Gambar 5. Ekspos Ceiling dengan rangka besi sebagai penempatan pencahayaan buatan

(Greenhost Hotel, 2017)

Area lobby terdiri dari lobby lounge di tengah dan area resepsionis yang terletak di sebelah kiri dari area masuk utama (Gambar 5 dan Gambar 6). Dinding pada area resepsionis masih menggunakan partisi tertutup untuk membatasi area back office yang lebih privasi dengan menggunakan rangka besi dan panel lembaran kayu pinus (warna kuning muda) yang membedakan area resepsionis dengan area masuk (kayu jati/coklat). Dengan ceiling yang lebih rendah untuk membuat fokus ruangan pada meja resepsionis seperti terlihat pada Gambar 6.

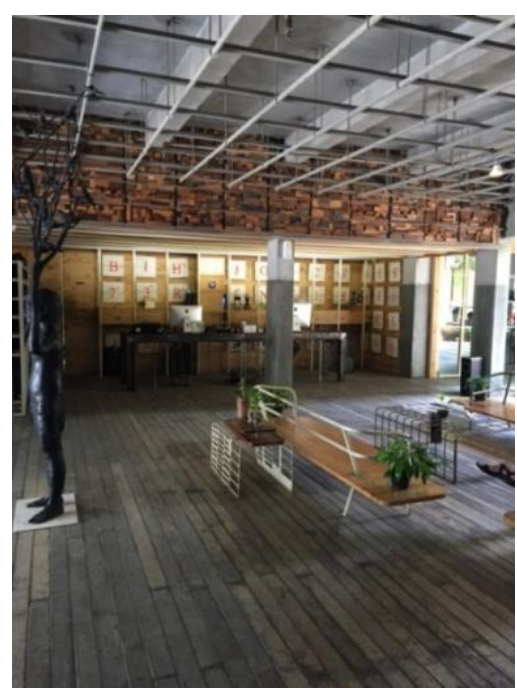

Gambar 6. Area Resepsionis dan Lobby Lounge (Dokumentasi Pribadi, 2017)

Bangunan yang ramah lingkungan di hadirkan dengan penggunaaan materialmaterial bekas pakai yang diupcycle. Pada salah satu sudut tampak depan bangunan hotel ini sudah terasa penggunaan material upcycle dengan penggunaan kayu bekas yang dijadikan pembalut dinding.

Pemilihan material pada furnitur area lobby mengikuti konsep arsitektur dan elemen desain interior dengan menggunakan kombinasi besi dan kayu. Seperti pada meja resepsionis dan juga furniture lobby lounge (kursi dan meja). Penggunaan material ini memperkuat konsep ramah lingkungan karena kayu yang digunakan merupakan kayu-kayu sisa olahan yang dengan dimensi yang kecil dan digabungkan menjadi panel press. Seperti terlihat pada Gambar 7 dan

\section{Gambar 8.}




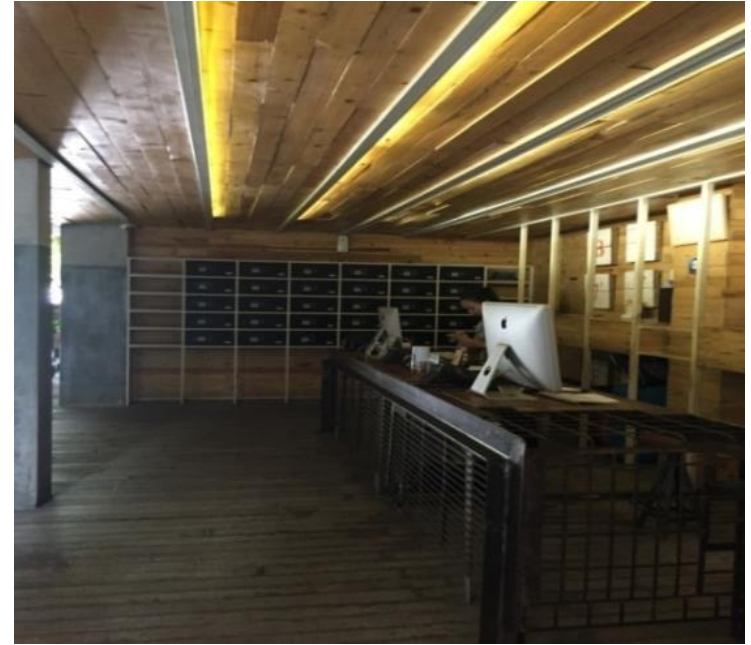

Gambar 7. Furniture pada Area Resepsionis (Dokumentasi Pribadi, 2017)

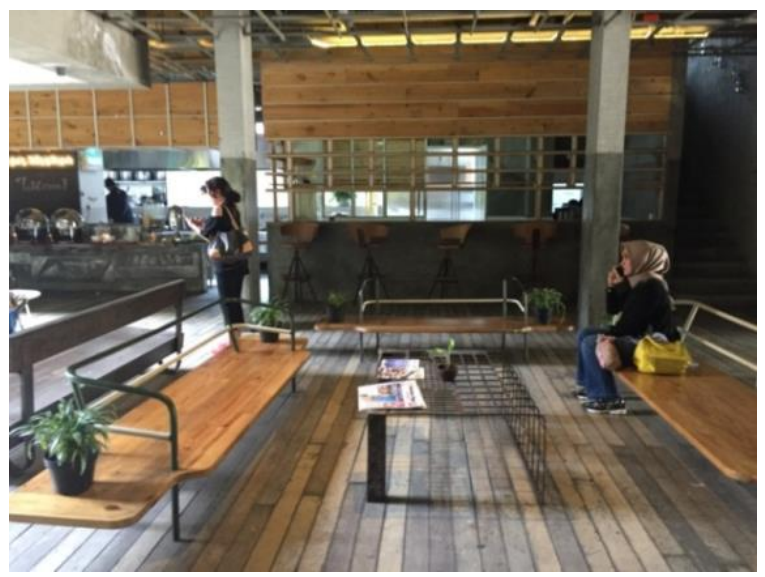

Gambar 8. Furniture pada Area Lobby Lounge (Dokumentasi Pribadi, 2017)

Secara keseluruhan penggunaan material interior dan pemilihan furniture pada area lobby masih mengacu pada konsep ramah lingkungan bangunan. Elemen aristektur menjadi dominan dengan material beton ekspos pada dinding, kolom dan ceiling. Elemen dinding interior ditambahkan unsur kayu dan besi, begitu juga dengan elemen ceiling yang menggunakan rangka besi untuk aksen ruang dan berfungsi sebagai penempatan lampu. Material lantai pada area lobby juga menggunakan ekspos beton yang dibuat dengan pola dan serat kayu. Furniture juga didesain sesuai dengan konsep ramah lingkungan dengan menggunakan material kayu dan besi. Data penggunaan material elemen interior dan furniture dapat dilihat melalui diagram pada Gambar 9.

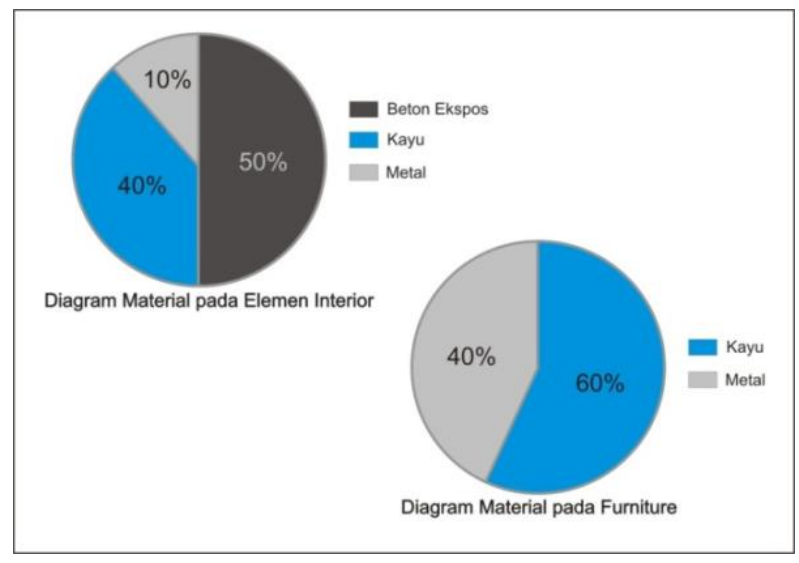

Gambar 9. Diagram penggunaan material ramah lingkungan pada elemen interior dan furniture area lobby lounge (Data Pribadi, 2017)

Diagram lingkaran diatas dibuat berdasarkan jumlah material pada elemen ruang dan furniture yang ada pada Lobby hotel Greenhost. Elemen interior (lantai, dinding, ceiling) menggunakan material beton $50 \%$, kayu $40 \%$ dan besi $10 \%$. Sedangkan furniture menggunakan material kayu sebanyak $60 \%$ dan $40 \%$ menggunakan material metal.Dengan adanya data tersebut dapat disimpulkan material ramah lingkungan yang paling banyak digunakan 
pada lobby hotel Greenhost adalah beton ekspos dan kayu.

\section{KESIMPULAN}

Tampilan depan Greenhost Boutique Hotel, nuansa green konsep sudah terasa dengan adanya tanaman-tanaman rambat yang menghiasi fasad bangunan. Koridorkoridor kamar diberikan tanaman hidroponik sebagai sentuhan hijau dan segar. Diyakininya dengan adanya tanaman tersebut, kesan keras dan panas bangunan modern akan berganti menjadi sebuah bangunan ramah lingkungan. Konsep elemen interior pembentuk ruangan semua area di Greenhost Hotel ini mengusung tema unfinished dalam pengertian penerapan material yang semua masih dalam taraf setengah jadi seperti acian semen berwarna abu-abu sebagai upaya untuk mengurangi penggunaan cat yang berlebihan. Untuk sistem listrik dan air juga demikian dihimbau untuk tidak menyalakan apabila sedang tidak digunakan.

Konsep kestabilan dan berkelanjutan ini yang sudah diterapkan dalam Greenhost Boutique Hotel dari aspek-aspek :

a. Konsep bangunan hijau dengan posisi bangunan berada di tengah area sehingga menjadi pusat dari udara dan gerak manusia sebagai pengguna serta penghargaan terhadap alam

b. Konsep Interior yang memiliki sirkulasi gerak dan udara ideal dengan perpaduan gaya dan tema yang mendukung konsep green

c. Konsep Furniture yang mendukung konsep interior dengan mengedepankan penggunaan material yang ramah lingkungan seperti kayu upcycle serta material yang rendah kadar limbah yang dihasilkan dan mudah direcycle serta digunakan kembali (reuse)

d. Konsep pencahayaan dan penghawaan yang meminimalkan penggunaan energi di pagi, siang dan malam hari. Mengoptimalkan penggunaan energi alami.

\section{DAFTAR PUSTAKA}

Bauer, Micheal. 2007. Green Building Guidebook for Sustainable Architecture, Germany : Springer Heidelberg

Dordrecht london : New York. Jin Kim, Jong. 1998. Sustainable Architecture Module : Introduction to Sustainable Design, USA : The University of Michigan.

Karyono, Tri Harso. 2010. Green

Architecture: Pengantar Pemahaman 
Arsitektur Hijau di Indonesia, Jakarta:

Penerbit PT Raja Grafindo Persada.

Karyono, Tri Harso. 2013. Arsitektur dan

Kota Tropis Dunia Ketiga : Suatu

Bahasan tentang Indonesia, Jakarta:

Penerbit PT Raja Grafindo Persada.

Lawson, Fred. 1999. Hotels \& Resorts,

Planning, Design and Refurbishment,

Architectural Press : Oxford. 


\title{
Pemahaman Pengaturan Warna Pada Foto Interior
}

\author{
Pengaturan White Balance di Kamera pada foto ruangan
}

\author{
Ferdy Tanumihardjo \\ Desain Komunikasi Visual, FSRD Untar \\ ferdit@fsrd.untar.ac.id
}

\begin{abstract}
Foto Interior merupakan bagian dalam proses pendokumentasian sebuah projek yang sedang atau sudah dilakukan pada sebuah ruang. Pemanfaatan foto interior sangat mendukung dalam rangka tahapan sebuah projek yang di garap.Dalam pembuatan foto Ineterior kempuan teknis dalam dunia fotografi harus sangat diperhatikan oleh seorang fotografer. Pemahaman tentang pengaturan White Balance mulai dari Daylight hingga Tungsten dan Color Temperatur. Semuanya ini guna menghasikan gambar yang sesuai dengan kondisi yang ada di lapangan. Kesalahan dalam pengaturan akan berdampak pada hasil foto yang dihasilkan.
\end{abstract}

Kata kunci: foto interior, white balance, daylight,tungsten,color temperatur

\section{PENDAHULUAN}

Pada saat ini kemajuan dalam dunia kreatif semakin berkembang. Tidak hanya dalam dunia seni rupa, seni tari, seni kriya dan seni musik, tetapi juga dalam dunia desain. Para desainer menciptakan karya yang semakin menarik. Hal ini didukung juga dengan kemajuan bidang teknologi yang semakin berkembang. Selain teknologi kemajuan pada bidang informasi juga mendukung kemajuan dalam dunia desain, kita dengan mudah mendapatkan informasi dan cepat dalam proses penciptaan karya.

Perkembangan dalam dunia kreatif pada akhirnya menuntut para pelakunya untuk lebih berinovasi dalam proses penciptaan karya. Hal ini tak terkecuali bagi para desainer interior, yang semakin hari semakin kreatif. Salah satu contoh adalah dalam hal pengaturan pencahayaan dalam ruang interior, pengaturan pencahayaan dengan berbagai efek dimunculkan dalam proses mendesain. Efek pendar dari lampu memilki warna yang sungguh menarik, hal ini sangat mendukung kesan yang ingin dihasilkan pada suatu ruang.

Penggunaan lampu tdak hanya sebagai penerang ruangan tetapi juga sebagai element utama yang mendukung terciptanya ruangan yang nyaman untuk ditempati. Saat ini produsen lampu berlomba-lomba menciptakan lampu yang hemat listrik. Selain itu warna yang muncul pada lampu yang ada semakin beragam. Semuanya ini menjadikan ruangan semakin nyaman dan menarik untuk ditempati. 
Warna-warna hangat menjadikan ruangan kamar lebih nyaman untuk ditinggali, sedangkan warna-warna dingin memberikan semangat tersendiri pada sebuah ruang untuk bekerja. Ini adalah salah satu efek yang dapat tercipta dengan penggunaan lampu.

Seorang desainer interior dalam proses penggarapan sebuah projek memerlukan proses dokumentasi yang baik. Salah satu proses dokumentasi sebuah projek interior dengan cara di foto. Foto interior merupakan bagian dari rangkaian rancangan dan penggarapan sebuah projek dari seorang Desainer Interior. Sebuah projek interior yang telah diselesaikan memerlukan pendokumen-tasian secara nyata dan akurat, agar sebuah projek yang telah dirancang dan ditata estetiknya tidak mengalami perubahan esensi ketika dilakukan proses dokumentasi. Hal ini merupakan hal utama yang perlu diperhatikan seorang fotografer ketika menggarap sebuah foto projek interior, pengaturan pencahayaan dan sudut pengambilan gambar sangat berpengaruh akan hasil dari gambar yang di dapat. "Photographs are taken by the egency of light travelling from the subject to the photoplane in the camera". (Triantaphillidou, 2009)

Tata letak lampu dan sudut jatuhnya cahaya sebuah ruang sangat mempengaruhi kesan yang ditimbulkan dari sebuah ruang. Pemotretan Interior harus memperhatikan peletakan dan penggunaan lampu tambahan. Pengambilan gambar foto interior memerlukan ketelitian tinggi dalam proses pengerjaanya, selain itu kemampuan teknis juga harus dikuasai, karena semuanya itu akan berpengaruh terhadap hasil akhir dari pemotretan ini.

Tetapi hal lain yang mendasar ketika proses pemotretan interior dilakukan adalah pemahaman sumber cahaya yang digunakan karena hal ini akan berkaitan dengan warna yang dihasilkan dari proses pemotretan yang dilakukan. " Light come from both natural and artificial light. Light sources differ in many ways, and the selection of a suitable source is base on a number of significant charac-teristics". (Triantaphillidou, 2009) Pengaturan White Balance (WB) di kamera pada awal sebelum pengambilan gambar harus dikuasai dan dilakukan oleh seorang fotografer. Kesalahan pengaturan WB di kamera akan menghasilkan warna yang tidak sesuai dengan kondisi di lapangan. White Balance di kamera harus disesuaikan dengan kondisi ruangan, bahkan antar ruang yang satu dengan ruang yang lain dalam satu lokasi projek yang sama bisa berbeda dalam pengaturan WB nya. Hal utama yang 
menjadikan perbedaan WB adalah dengan tampilan dari hasil pengamatan perbedaan sumber cahya dan perbedaan suhu cahaya yang ada dalam ruang tersebut. lapangan yang mendukung penelitian.

Dalam pegumpulan data lapangan penulis

Dalam proses penilitian dan penulisan ini penulis melakukan pengamatan dilapangan berkaitan dengan proses yang terjadi. Data yang didapat berasal dari kajian pustaka, pengamatan lapangan dan didukung dengan pengamatan visual secara langsung pada objek. Pemaparan ini dilakukan karena berdasarkan pengamatan penulis banyak hasil foto interior yang diciptakan tetapi terjadi perbedaan warna dengan kondisi dilapangan.

Maka dari itu penulis dalam hal ini memaparkan penjelasan berkaitan dengan White Balance dan Color Temperatur pada kamera, khususnya guna foto interior. Dari penulisan ini diharapkan dapat membantu dan manambah wawasan bagi fotografer dalam proses pra foto projek interior.

\section{METODE}

Dalam penelitian ini penulis menggunakan Metode Kualitatif dimana penulis menggunakan data lapangan yang dipadukan dengan data literatur. Hal ini dilakukan penulis karena penulis melihat data yang didapat dilapangan harus didukung oleh data literatur yang mendasarinya, ditambah lagi melakukan dan mengambil contoh langsung di lapangan dengan cara melakukan pemotretan pada beberapa ruang dengan berbagai sumber pencahayaan dan berbagai macam pengaturan White Balance di kamera. Dan Penulis melakukan analisa dan diskusi dengan beberapa Fotografer yang melakukan pemotretan Interior hal ini guna mendapatkan data empiris dari pengalaman dan temuan dilapangan yang dilakukan atau pernah dialami langsung dari Fotografer Interior.

Karena ditiap ruang memiliki pencahayaan yang tidak sama maka perlu diambil contoh foto dari beberapa ruang. Selain itu penulis juga melakukan pengumpulan data dengan berdasarkan literatur guna mendukung temuan data lapangan. Pengumpulan data dilakukan bukan hanya pada satu objek, tetapi pada beberapa objek guna mendapatkan hasil yang lebih tepat dan akurat.

\section{HASIL DAN PEMBAHASAN}

Fotografi dalam dunia desain interior merupakan bagian yang penting. Setiap projek yang dikerjakan baik yang sudah 
selesai maupun dalam tahap pengerjaan perlu fotografi sebagai bagian dalam dokumentasi projek. Tanpa disadari, fotografi telah menjadi bagian yang tidak bisa dipisahkan lagi.

'Photos interior and architecture is part of the photo documentation. Jon Reiger 1996 said: "The key to the successful take a photo documentation is make a photo clear, is the careful conceptualization of the link between the research topic and the photographs being taken" it quoted from the book Visual Methodologies, an Introduction to the Interpretation of Visual Materials, Gilian Rose. (Rose, 2015)

Dari hasil penelitian yang dilakukan penulis, desainer interior akan melakukan pemotretan projek yang mereka tangani, guna dijadikan dokumentasi nyata dari projek yang mereka garap. Desainer interior dalam proses mendesain terkadang sudah memilki gambar 3Dimensi dari projek tersebut. Tetapi tidak jarang ada perubahan ketika proses projek berlangsung. Foto interior merupakan wujud nyata dari apa yang ada dilapangan.

Teknik pemotretan interior berbeda dengan teknik pemotretan foto model ataupun produk, dalam pemotretan foto interior fotografer harus memperhatikan dengan cermat bahan material setiap produk yang ada di lokasi, tata letak cahaya, dan sumber cahaya yang ada dalam ruangan tersebut. Hal ini sangat berpengaruh terhadap hasil foto yang dihasilkan.

Seperti kita ketahui bahwa sumber cahaya ada 2, yaitu alami dan buatan. Sumber cahaya alami yang utama adalah matahari. Sedangkan sumber cahaya buatan adalah segala jenis lampu baik itu yang berasalah dari benda elektornik, maupun cahaya yang muncul karena ada pengaruh panas." Artificial sources are classified by the method use to produce the light, including burning heating, electric sparks, arcs or discharges and luminescence." (Triantaphillidou, 2009)

Kedua sumber cahaya ini memilki suhu cahaya yang berbeda, suhu cahaya yang disebut juga Color Temperatur yang memiliki satuan ukur Kelvin. "Color Tempratur of a light source is the temperature of a full radiator that would emit radiation of substantialy the same spectral distribution in the visible region as the radiation from the light source". (Triantaphillidou, 2009). Mata manusia dapat melihat warna cahaya pada spectrum cahaya dari 400 -700 NanoMeter, warna-warna yang dapat dilihat adalah Merah, Jingga, Kuning, Hijau, Biru, Nila dan Ungu. 


\begin{tabular}{|l|c|l|}
\hline \multicolumn{1}{|c|}{ Warna } & Interval Panjang Gelombang & Tampilan \\
\hline Merah & $\sim 700-635 \mathrm{~nm}$ & \\
\hline Jingga / Oranye & $\sim 635-590 \mathrm{~nm}$ & \\
\hline Kuning & $\sim 590-560 \mathrm{~nm}$ & \\
\hline Hijau & $\sim 560-490 \mathrm{~nm}$ & \\
\hline Biru & $\sim 490-450 \mathrm{~nm}$ & \\
\hline Violet/Ungu & $\sim 450-400 \mathrm{~nm}$ & \\
\hline
\end{tabular}

Tabel 1 : Color Temperatur

Sumber: (pengaruh warna terhadap performansi, 2011)

http://ergonomi-fit.blogspot.co.id

Pada Color Tempratur kita mengenal adanya warna panas dan warna dingin, ini didasari pada suhu cahaya yang dihasilkan. Warna panas muncul dari lampu yang kemerahan, sedangkan warna dingin mucul dari lampu yang warnanya kebiruan, secara sederhananya dapat dikatakan demikian, tetapi ternyata perbedaan warna pada lampu memiliki Color Temperatur yang berbedabeda atau ada perbedaan derajat Kelvinnya.

Perbedaan warna dari sumber cahaya akan sangat berpengaruh pada hasil foto yang dihasilkan. Untuk kamera digital, hal ini harus sangat diperhatikan, terlebih untuk foto projek interior. Maka dari itu perlu diatur White Balance di kamera. White Balance di kamera berfungsi untuk menyeimbangkan warna putih yang muncul dari sumber cahya sehingga warna cahaya yang jatuh pada objek tepat sesuai dengan kondisinya.

Pengaturan White Balance dikamera digital dapat dilakukan secara manual ataupun otomatis. Pengaturan manual berarti seorang fotografer mengatur derajat Kelvin yang akan digunakan untuk pemotretan objek tersebut, sedangkan untuk pengaturan otomatis fotografer dapat memilih fitur yang telah disediakan kamera.

\begin{tabular}{|l|c|c|c|c|c|c|c|}
\hline WB Setting & -3 & -2 & -1 & $\mathrm{O}^{*}$ & +1 & +2 & +3 \\
\hline Sunlight & $+460 \mathrm{k}$ & $+300 \mathrm{k}$ & $+140 \mathrm{k}$ & $5200 \mathrm{k}$ & $-120 \mathrm{k}$ & $-260 \mathrm{k}$ & $-360 \mathrm{k}$ \\
\hline Shade & $+820 \mathrm{k}$ & $+520 \mathrm{k}$ & $+240 \mathrm{k}$ & $7000 \mathrm{k}$ & $-240 \mathrm{k}$ & $-460 \mathrm{k}$ & $-680 \mathrm{k}$ \\
\hline Cloudy & $+580 \mathrm{k}$ & $+360 \mathrm{k}$ & $+180 \mathrm{k}$ & $6000 \mathrm{k}$ & $-180 \mathrm{k}$ & $-360 \mathrm{k}$ & $-500 \mathrm{k}$ \\
\hline Incandescent & $+300 \mathrm{k}$ & $+200 \mathrm{k}$ & $+100 \mathrm{k}$ & $3000 \mathrm{k}$ & $-80 \mathrm{k}$ & $-160 \mathrm{k}$ & $-240 \mathrm{k}$ \\
\hline Fluorescent & $+280 \mathrm{k}$ & $+180 \mathrm{k}$ & $+100 \mathrm{k}$ & $4200 \mathrm{k}$ & $-80 \mathrm{k}$ & $-160 \mathrm{k}$ & $-240 \mathrm{k}$ \\
\hline Flash & $+600 \mathrm{k}$ & $+400 \mathrm{k}$ & $+200 \mathrm{k}$ & $5400 \mathrm{k}$ & $-200 \mathrm{k}$ & $-400 \mathrm{k}$ & $-600 \mathrm{k}$ \\
\hline
\end{tabular}

Tabel 2 : Derajat Kelvin pada pengaturan White Balance. Sumber : (Peterson, 2010)

Ada beberapa fitur yang dapat dipilih pada pengaturan White Balance di kamera. Ada Auto White Balance (AWB), Daylight, Tungsten / Incandescent, Cloudy, Fluorescent, Flash dan Shade yang semuanya memiliki pengukuran Color Temperatur yang berbeda.

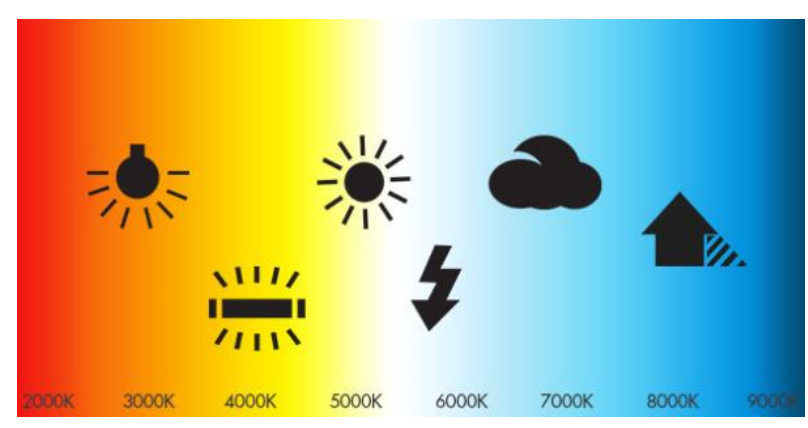

Gambar 1 : White Balance di Kamera Sumber : (Photography 101- white balance, 2016)

Daylight, pada kamera digital digambarkan dengan matahari yang bersinar, hal ini menunjukkan sumber cahaya berasal dari sinar matahari yang mengarah pada 
objek. Pengaturan White Balance di Daylight memiliki Color Tempratur 5500 Kelvin. Penggunaan White Balance Daylight dilakukan pada tempat yang sumber cahaya dari matahari yang bersinar cerah menerangi objek.

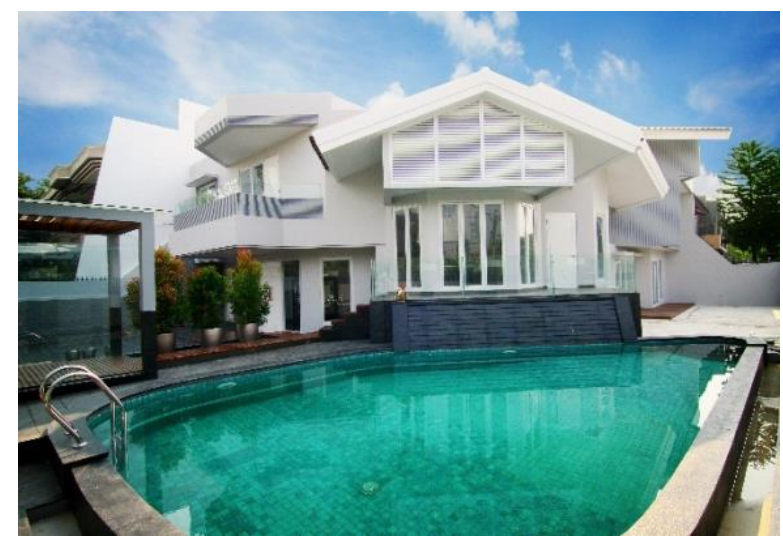

Gambar 2 : Pengaturan White Balance Daylight, pada saat pemotretan outdoor

Sumber : Dokumentasi Pribadi Penulis, 2012

Tungsten atau Incandescent, pada kamera digital digambarkan dengan lampu bolam yang berpijar. Hal ini didasari oleh warna yang muncul dari lampu pijar berwarna kekuningan. Pengaturan White Balance pada Tungsten atau Incandescent memiliki Color Temperatur 3200 K. Pengaturan White Balance Tungsten dilakukan pada tempat yang sumber cahayanya memiliki pendar cahaya yang berwarna kuning. Hal ini dilakukan agar menyeimbangkan warna kuning yang ada sehingga warna mendekati kondisi White Balance Daylight.
Cloudy, pada kamera digital digambarkan dengan awan yang bergumpal. Hal ini didasari oleh kondisi Color Temperatur yang berbeda ketika cuaca sedang berawan. Pengaturan White Balance pada Cloudy atau Incandescent memiliki Color Temperatur 6000 K. Penggunan White Balance Coudy dapat dilakukan pada saat pemotretan diluar ruang pada objek yang terkena sinar matahari tetapi kondisi cuaca sedikit berawan.

Fluorescent, pada kamera digital digambarkan dengan lampu $T L$ yang menyala. Pengaturan White Balance pada Fluorescent memiliki Color Temperatur 4200 K. Fungsi pengaturan White Balance Fluorescent adalah menekan warna biru atau hijau yang mucul dari pancara lampu TL yang menyala.

Flash, pada kamera digital digambarkan dengan kilat. Pengaturan White Balance pada Flash memiliki Color Temperatur $5400 \mathrm{~K}$. Pengaturan White Balance Flash ada kamera dilakukan bila dalam pemotretan sumber cahaya hanya satu yaitu Flash, hal ini dilakukan guna menekan warna putih dari lampu flash sehingga Color Temperatur mendekati Daylight. 


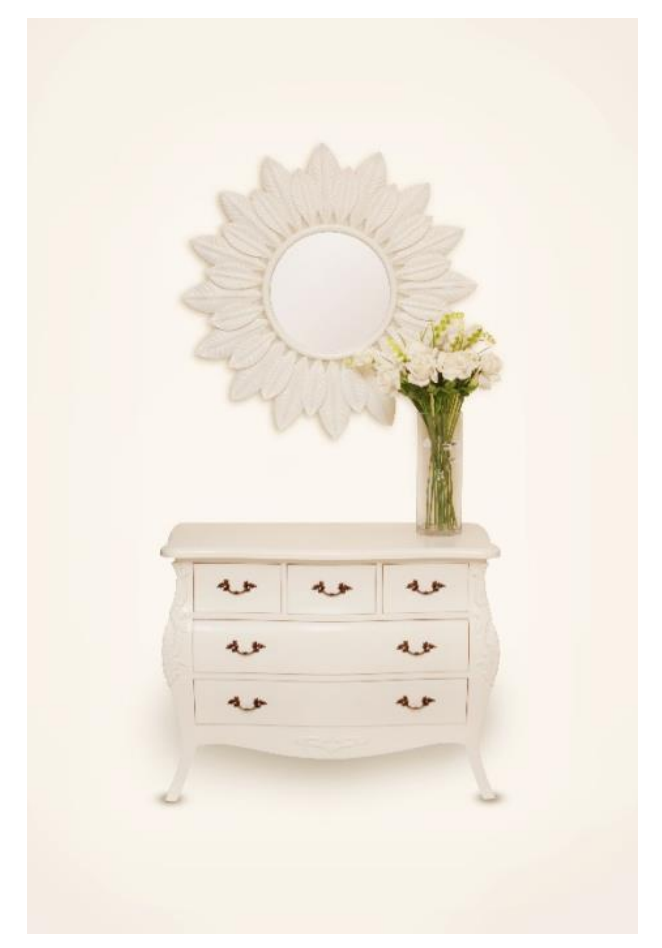

Gambar 3 : Pengaturan White Balance Flash Sumber : Dokumentasi Pribadi Penulis, 2012

Shade, pada kamera digital digambarkan dengan rumah dengan jatuh bayangan. Pengaturan White Balance pada Shade memiliki Color Temperatur $7000 \mathrm{~K}$. Pengaturan White Balance Shade ada kamera dilakukan bila pemotretan dilakukan di luar ruang dalam kondisi cahaya matahari terik dan jatuh banyangan dari awan atau objek lain cukup keras. Hal ini akan mempengaruhi Color Temperatur, maka perlu diseimbangkan agar warna yang dihasilkan dari pemotretan mendekati Daylight.

Auto White Balance (AWB), pada pengaturan White Balance ini kamera akan secara otomatis mengatur kondisi Color Tempratur pada ruangan atau objek yang dibidik. Tetapi ada kelemahan dari pemilihan Auto White Balance di kamera, yaitu ketika sumber pencahayaan berasal dari lebih dari satu sember dan memilki Color Temperatur yang cukup berbeda. Maka hasil kondisi warna yang mucul pada foto bisa tidak sesuai dengan kondisi asli objek.

Pada khasus foto interior seorang fotografer harus sangat menguasai pengaturan White Balance, karena tidak jarang dalam satu ruang lampu yang digunakan memilki pendar warna yang beragam, ada yang kuning, putih, biru, dan lain sebagainya. Pengaturan White Balance harus dilakukan secara manual atau sesuai dengan derajat Kelvin dari ruangan tersebut. Kesalahan dalam pengaturan White Balance menjadikan warna yang tampil pada hasil foto tidak sesuai, misalnya dalam ruangan tersebut tidak ada lampu yang Color Temperaturnya 3200K, tetapi dipilih pengaturan White Balance adalah Tungsten, maka warna yang mucul dalam foto tersebut adalah kehijauan. 


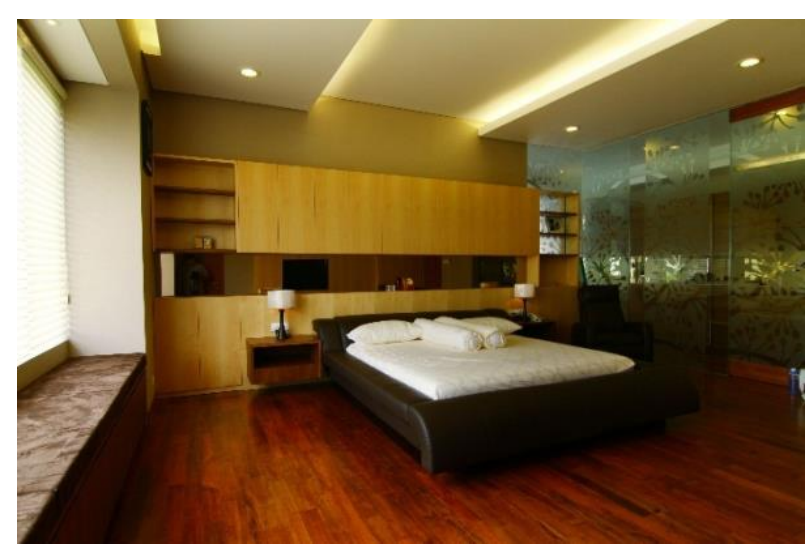

Gambar 4. Pengaturan White Balance pada ruangan dengan 2 sumber cahaya Sumber : Dokumen Pribadi Penulis, 2010

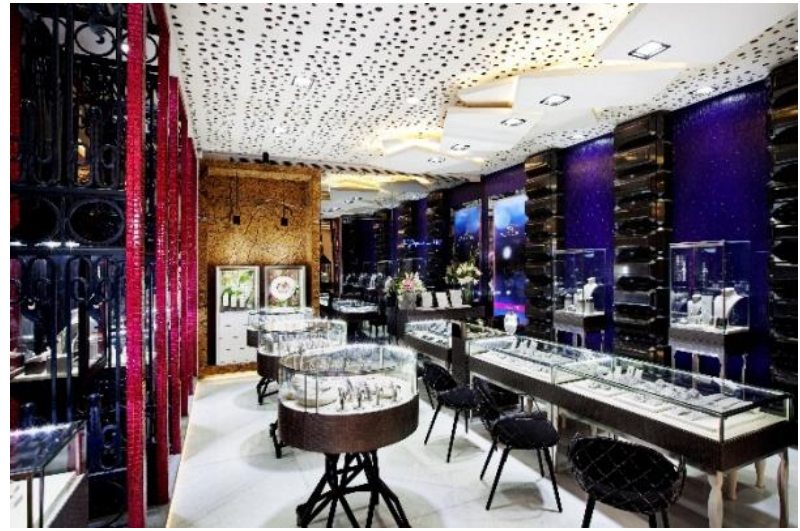

Gambar 5 : Sumber cahaya memiliki perbedaan Color Tempratur Sumber : Dokumentasi Pribadi Penulis, 2013

\section{SIMPULAN}

Dari hasil penelitian dan pengamatan dilapangan oleh penulis, maka dapat disimpulkan bahwa pengaturan White Balance di kamera harus dilakukan ketika seorang fotografer dalam foto interior. Hal ini karena dalam satu ruang mungkin ditemukan dua sumber cahaya dengan Color Temperatur yang berbeda. Tidak disarankan pemotretan foto interior fotografer menggunakan fitur Auto White Balance, karena warna yang dimuculkan bisa berbeda dengan kondisi dilapangan.

Dalam penelitian ini ada kekurangan yang akan menjadi pembahasan dalam penelitian penulis berikutnya adalah berkaitan dengan perbedaan ukuran sensor pada kamera digital yang berpengaruh pada perbedaan hasil warna dari pemotretan. 


\section{UCAPAN TERIMA KASIH}

Dalam pembuatan penelitian dan penulisan ini penulis mengucapkan terima kasih kepada semua pihak yang telah membantu dalam proses penelitian dan penulisan ini. Tidak lupa juga Penulis mengucapkan Puji dan Syukur kepada Tuhan Yang Maha Esa atas bimbingan dan perlindungannya dalam proses penelitan dan penulisan ini, sehingga karya penulisan ini dapat terselasikan. Secara khusus penulis mengucapkan terima kasih kepada rekanrekan fotografer interior yang telah membagikan pengalaman dalam proses dokumentasi foto interior.

\section{DAFTAR PUSTAKA}

Triantaphillidou, E. A. (2009). The Manual of Photography. (10, Ed.) london: focal press. pengaruh warna terhadap performansi. $(2011,3)$.

Retrieved 1 2018, from http://ergonomifit.blogspot.co.id: http://ergonomifit.blogspot.co.id/2011/03/pengaruhwarna-terhadap-performansi 28.html

Peterson, M. (2010, 7). white-balance-areyou-rgb-savvy-moose-peterson.

Retrieved 1 2018, from http://www.cardinalphoto.com: http://www.cardinalphoto.com/content /white-balance-are-you-rgb-savvy-

moose-peterson

Rose, G. (2015). Visual Methodologies:An Introduction to the Researching of Visual Materials (Vol. 4). Singapore: SAGE.

Photography 101- white balance. $(2016,8)$.

Retrieved 1 2018, from

http://www.acdsystems.com/: http://www.acdsystems.com/en/commu nity/post/white-balance 


\title{
Evaluasi Proses dan Pemecahan Masalah Desain pada Interior Hotel Holiday Inn Sunter Kemayoran - Jakarta
}

\author{
Adi Ismanto \\ Universitas Tarumanagara \\ adii@fsrd.untar.ac.id
}

\begin{abstract}
Proses desain dan pemecahan masalah desain interior pada fasilitas publik seperti hotel sangat menarik untuk dijadikan sebagai acuan dari proses belajar-mengajar desain interior di Perguruan Tinggi. Hotel merupakan fasilitas publik yang sangat kompleks mencakup berbagai macam aktivitas manusia pada semua fasilitas perancangan interior. Banyak proyek desain modern yang terlalu rumit untuk diselesaikan secara memuaskan oleh proses konvensional tua. Banyak kesalahan yang dibuat dengan proses desain, dan menjadi tidak berguna ketika desainer atau tim kerja melaksanakan proyek. Penelitian ini mencoba untuk menunjukkan fakta proses desain yang digunakan oleh desainer interior, berbagai jenis masalah dan pemecahan permasalahan desain pada hotel berbintang 4 yaitu: Holiday Inn Sunter, Kemayoran Jakarta, yang merupakan hotel Holiday Inn pertama di Jakarta yang diresmikan tahun 2014. Hotel ini juga memiliki konsep tema desain yang unik sehingga dijadikan acuan oleh pihak pengelola InterContinental Hotel Group (IHG) untuk membuat hotel Holiday Inn lainnya, terutama untuk tipe hotel Holiday Inn Express. Teknik pengumpulan data pada penelitian ini dilakukan dengan cara mewawancara desainer yang masih aktif bekerja di konsultan desain Hadiprana selaku perancang hotel ini dan mengikuti proses desain dengan beberapa pertanyaan yang ditampilkan dalam bentuk narasi, skema, dan tabel. Melalui hasil wawancara dengan desainer hotel Holiday Inn Kemayoran Jakarta dapat disimpulkan bahwa proses desain hotel Holiday Inn Kemayoran merupakan karya yang berhasil dengan gaya desain yang masih bertahan hingga saat ini. Hasil desain adalah cerminan dari Tim desain yang solid dan mampu memecahkan masalah desain dengan kreatif dan inovatif sehingga mudah dipahami dan diterima oleh klien, operator dan pengguna hotel
\end{abstract}

Kata kunci: desain interior, evaluasi, hotel, implementasi, proses desain.

\section{PENDAHULUAN}

InterContinental Hotels Group (IHG) secara resmi membuka hotel Holiday Inn pertama di Sunter, Kemayoran Jakarta. Hotel Holiday Inn Kemayoran merupakan hotel bintang 4 yang didesain oleh Hadiprana sebagai salah satu konsultan desain interior dan arsitektur terbesar di Indonesia. Hasil perancangan Hotel Holiday Inn ini sangat diapresiasi oleh pemilik dan operator IHG, seperti yang dikatakan oleh Clarence Tan, Kepala Operasional IHG Se-Asia Tenggara saat peresmian hotel pada awal tahun 2014. Clarence Tan mengatakan bahwa IHG merasa senang menyambut Hotel Holiday Inn yang pertama di salah satu kota yang berkembang paling cepat di Asia.

Holiday Inn Jakarta Kemayoran berada di lokasi yang strategis, dekat dengan pusat kota Jakarta dan beberapa kawasan bisnis dan objek wisata. Desain interior Holiday Inn Sunter memiliki sub tema yang unik dengan garis tema umum yang menyatukan keseluruhan ruang yang ada, seperti restoran 
Botany/All Day Dining (Gambar. 1) dalam hotel untuk menikmati sebuah perpaduan rasa antara lokal dan internasional atau Habitat Bar Lounge (Gambar. 2) untuk bersantai dengan secangkir kopi atau memesan koktail saat pertama kali memasuki hotel atau kamar hotel yang menyajikan grafis siluet pohon yang membuat ruangan menjadi lebih tenang dan nyaman dengan pemilihan material serta warna yang sesuai.

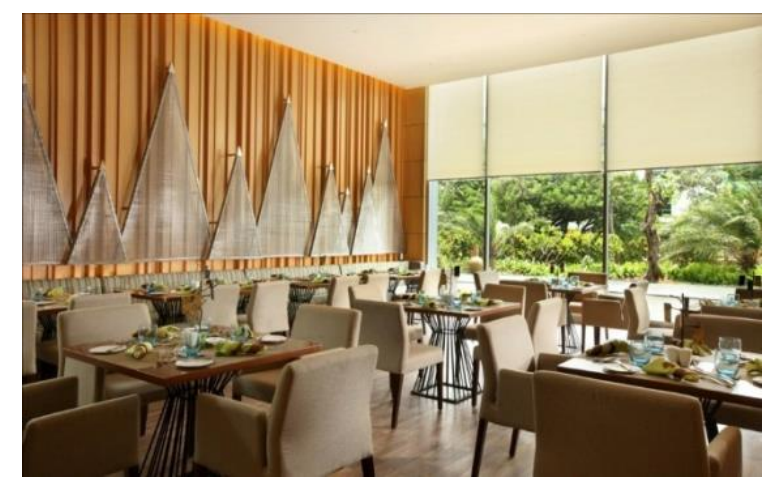

Gambar 1. Botany All Day Dining

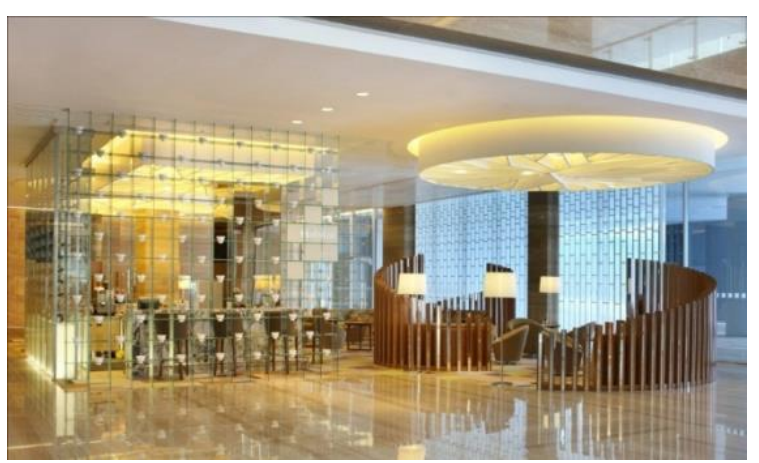

Gambar 2. Lobby Lounge Holiday Inn Sunter

Pemilihan nama dan pengolahan elemen ruang ini menjadi unik dan sangat menarik untuk diteliti bagaimana proses desain interior itu berawal. Selain itu penelitian yang menjelaskan proses desain interior secara menyeluruh, dari awal mulai perancangan, pemecahan masalah hingga post-occupancy evaluation (POE) pada fasilitas publik seperti hotel belum banyak dilakukan.

\section{METODE}

Desain penelitian ini adalah deskriptif kualitatif. Subyek penelitian yang bertindak sebagai partisipan dipilih dengan metode purposive sampling yang dipilih berdasarkan kriteria tertentu, yaitu desainer interior, akademisi, mahasiswa dan kalangan umum. Penelitian ini dilakukan di Jakarta. Instrumen penelitian yang digunakan adalah: alat perekam gambar dan suara, peralatan tulis, dan keperluan pelengkapnya. Analisis data dilakukan berdasarkan verbatim transkripsi hasil kuesioner dan wawancara pengguna jalan (in depth interview) dan observasi selama kegiatan penelitian berlangsung.

\section{HASIL DAN PEMBAHASAN}

Observasi dan wawancara dilakukan untuk mendapatkan data akurat bagaimana proses desain hingga implementasi berjalan dalam proyek ini. Narasumber adalah salah satu desainer yang masih berkerja sebagai desainer senior di konsultan desain Hadiprana yang pernah tergabung dalam tim 
desain untuk proyek Holiday Inn Kemayoran.

Kesimpulan Proses desain, pemecahan masalah dan durasi waktu yang terjadi pada proyek Holiday Inn dapat dilihat pada Tabel. 1

Tabel 1. Proses desain dan pemecahan masalah proyek Holiday Inn Kemayoran.

\begin{tabular}{|c|c|c|}
\hline $\begin{array}{l}\text { Poses } \\
\text { Desain }\end{array}$ & $\begin{array}{c}\text { Permasalahan } \\
\text { Desain }\end{array}$ & Pemecahan Masalah \\
\hline $\begin{array}{l}\text { Design } \\
\text { Brief } \\
\text { Maret } \\
2009\end{array}$ & $\begin{array}{l}\text { - Standar Operator } \\
\text { (IHG) dan Klien } \\
\text { menginginkan } \\
\text { sebuah hotel } \\
\text { bintang } 4 \text { dengan } \\
\text { konsep 'modern- } \\
\text { unique-elegant' } \\
\text { design with 'north- } \\
\text { market' oriented. }\end{array}$ & $\begin{array}{l}\text { - Lokasi yang dekat } \\
\text { pantai dan kurang } \\
\text { pohon peneduh } \\
\text { menjadi inpirasi untuk } \\
\text { menjadikan fasilitas } \\
\text { hotel sebuah tempat } \\
\text { berlindung yang sejuk } \\
\text { dengan konsep } \\
\text { “Oasis” di tengah area } \\
\text { yang panas dan } \\
\text { kering. Yang berarti } \\
\text { sebuah area terisolasi } \\
\text { dengan vegetasi di } \\
\text { area yang kering. }\end{array}$ \\
\hline $\begin{array}{l}\text { Prelimin } \\
\text { ary } \\
\text { Design } \\
\text { April } \\
2009\end{array}$ & $\begin{array}{l}\text { - Penjelasan Konsep } \\
\text { desain. } \\
\text { desain awal sebagai } \\
\text { sebuah acuan } \\
\text { referensi klien } \\
\text { untuk mendapatkan } \\
\text { gambaran desain } \\
\text { secara keseluruhan. } \\
\text { - menentukan } \\
\text { konsep desain yang } \\
\text { memiliki kesatuan } \\
\text { yang utuh sebagai } \\
\text { landasan desain. }\end{array}$ & $\begin{array}{l}\text { - Menyusun konsep } \\
\text { desain dengan tema } \\
\text { "a reflection of tree, } \\
\text { vegetations and } \\
\text { greenery". } \\
\text { - Area Lobby dibuat } \\
\text { sebagai bagian bawah } \\
\text { pohon dengan konsep } \\
\text { "The Geomatric Patern } \\
\text { of Tree Trunk" } \\
\text { - Bar Lounge di desain } \\
\text { dengan konsep } \\
\text { Vegetasi } \\
\text { - All Day Dining di } \\
\text { desain dengan konsep } \\
\text { vegatasi hutan pinus, } \\
\text { menciptakan "a dense } \\
\text { pine forest in the } \\
\text { modern graphic style". } \\
\text { - Guest Room } \\
\text { menggunakan } \\
\text { vegetasi dari bagian } \\
\text { atas pohon, dengan } \\
\text { desain yang lebih } \\
\text { "light and bright" }\end{array}$ \\
\hline
\end{tabular}

\begin{tabular}{|c|c|c|}
\hline $\begin{array}{l}\text { Design } \\
\text { Develop } \\
\text { ment } \\
\text { (Juni } \\
2009 \text { - } \\
\text { Juli } \\
2011 \text { ) }\end{array}$ & $\begin{array}{l}\text { - Pengembang } \\
\text { desain awal, } \\
\text { dengan detail pada } \\
\text { ruangan lainnya. } \\
\text { - Proses approved } \\
\text { design_untuk } \\
\text { dilanjutkan ke } \\
\text { tahap Gambar } \\
\text { Konstruksi sebagai } \\
\text { acuan pelaksanaan } \\
\text { konstruksi. }\end{array}$ & $\begin{array}{l}\text { - Mengembangkan } \\
\text { Lobby Lounge dengan } \\
\text { konsep yang lebih } \\
\text { kuat sebagai bagian } \\
\text { dari penarik perhatian } \\
\text { ruang dengan konsep } \\
\text { "Big Tree Root" } \\
\text { sebagai lounge chair } \\
\text { yang juga menjadi } \\
\text { artwork yang eye } \\
\text { catching. } \\
\text { - Pengembangan } \\
\text { Desain Executive } \\
\text { Lounge, Meeting } \\
\text { Room dan Ball Room } \\
\text { dengan konsep } \\
\text { Vegetasi dan patern } \\
\text { sarang lebah. } \\
\text { - Pengembangan } \\
\text { deain ruangan lainnya, } \\
\text { seperti: All Day Dining, } \\
\text { Health Club dan Guest } \\
\text { Room. }\end{array}$ \\
\hline $\begin{array}{l}\text { Constru } \\
\text { ction } \\
\text { Docume } \\
\text { nt } \\
\text { (Juni } \\
2009 \text { - } \\
\text { Juli } \\
2011 \text { ) }\end{array}$ & $\begin{array}{l}\text { - Proses Gambar } \\
\text { kerja dari image } \\
\text { visual desain. } \\
\text { - Penjelesan } \\
\text { Gambar Teknis dan } \\
\text { Detail. }\end{array}$ & $\begin{array}{l}\text {-Merekomendasikan } \\
\text { Manajemen } \\
\text { Konstruksi (MK) yang } \\
\text { kompeten. } \\
\text { - Komunikasi dengan } \\
\text { klien dan operator } \\
\text { untuk persetujuan } \\
\text { desain. } \\
\text { - Komunikasi dalam } \\
\text { tim desain dengan tim } \\
\text { produksi gambar } \\
\text { kerja. }\end{array}$ \\
\hline $\begin{array}{l}\text { Constru } \\
\text { ction } \\
\text { Phase \& } \\
\text { Supervi } \\
\text { sion } \\
\text { (Juni } \\
2009 \text { - } \\
\text { April } \\
2012 \text { ) }\end{array}$ & $\begin{array}{l}\text { - Proses } \\
\text { pelaksanaan } \\
\text { konstruksi sebagai } \\
\text { realisasi desain. } \\
\text { - Down spec dari } \\
\text { desain yang } \\
\text { disetujui. } \\
\text { - ketidaksesuaian } \\
\text { pelaksanaan } \\
\text { dengan desain. }\end{array}$ & $\begin{array}{l}\text {-Merekomendasikan } \\
\text { Konstraktor yang } \\
\text { kompeten. } \\
\text { - Memastikan ke klien } \\
\text { dan operator bahwa } \\
\text { desain harus sesuai } \\
\text { dilaksanakan dengan } \\
\text { arahan tim desain } \\
\text { (penyesuaian budget) } \\
\text { agar mendapatkan } \\
\text { hasil yang masksimal. } \\
\text { - Melakukan supervisi } \\
\text { berkala dan meeting } \\
\text { koordinasi dengan } \\
\text { MK. }\end{array}$ \\
\hline
\end{tabular}


Proses desain Holiday Inn sunter Komunikasi menjadi bagian utama memakan waktu kurang lebih 3 tahun hingga selesai tahapan konstruksi. Dalam prosesnya banyak permasalahan yang muncul terkait desain dan teknis pelakasanaan. Yang menjadi catatan penting dan waktu kritis dalam proses desain ini adalah bagaimana tim desain menangkap esensi dari kebutuhan dan keinginan klien terhadap produk desain yang akan dihasilkan, kemudian membuat konsep (dasar pemikiran) yang mampu menjadi acuan desain dan diterima oleh klien. Hasil kuesioner yang diberikan kepada pengguna dan operator memperlihatkan hasil yang sesuai antara permasalahan desain, pemecahan masalah dengan konsep desain dan hasil akhir yang mudah dipahami oleh pengguna dan operator, artinya desain hotel Holiday Inn Kemayoran dapat dianggap berhasil.

\section{KESIMPULAN}

terpenting untuk keberhasilan proyek ini.

Proses desain dari sebuah proyek yang sangat kompleks seperti hotel memerlukan tim yang cukup solid. Pengalaman dalam melaksanakan tipe proyek yang sama akan lebih memudahkan proses desain dalam memecahkan permalasahan yang ada, dalam hal ini konsultan sebesar hadiprana memiliki struktur organisasi yang memungkinkan untuk menghasilkan karya desain yang baik.

Permasalahan desain yang terjadi selama proses desain dan pelaksanaan proyek hotel Holiday Inn Kemayoran dapat diminimalisir semenjak awal proyek. kondisi awal persiapan klien dengan kemampuan dana yang cukup, tim manajemen konstruksi dan kontraktor yang kompeten, banyak membantu proses desain dan pelaksanaan dengan komunikasi yang tetap terjaga baik untuk hasil yang sesuai dengan arahan dan harapan klien.

Proses desain sebuah hotel adalah rangkaian proses yang sangat panjang, tetapi masa kritis berada pada proses awal dari design brief klien dan operator. Menjadi sangat penting untuk tim desain memahami kebutuhan dan keinginan klien dengan menghasilkan konsep desain yang sesuai.

\section{DAFTAR PUSTAKA}

Oscar Barros, (Mei 2007) Business Process and Architecture Design, Departemen Teknik Industri, Universitas Chili, United State of America.

Brown, T. (2009). Change by Design. New York: Harper Collins. 
Browne, M. N., Keeley, S. M. (2011) Asking

the Right Questions: A Guide to Critical

Thinking. New York: Longman.

Design Thinking. (2012). Harvard Business

Review, 86. 


\title{
Analisa Penerapan Material Pada Lobby Hotel Best Western Premier Jakarta Selatan
}

\author{
Letitia Rena ${ }^{1}$, Giovani Angelina², Maitri Widya Mutiara ${ }^{3}$ \\ Fakultas Seni Rupa dan Desain Universitas Tarumanagara ${ }^{1,2,3}$ \\ maitrim@fsrd.untar.ac.id
}

\begin{abstract}
Lobby memiliki peran penting dalam sebuah hotel, karena lobby pada hotel merupakan tempat yang pertama kali ditemui dan menjadi pusat sirkulasi bagi pengunjung. Dengan demikian, diperlukan perancangan interior yang mempertimbangkan segala aspek. Perancangan interior pada dasarnya merupakan pembentukan suasana ruang dengan memadukan unsur-unsur pembentuk ruang, warna, material pada lantai, dinding, dan plafon. Pemilihan material yang baik pada perancangan interior dapat menciptakan suasana/citra ruang menjadi lebih hidup dan nyaman. Penggunaan material pada lobby hotel dapat menimbulkan suasana ruang yang berbeda, dikarenakan setiap material memiliki sifat dan karakteristik yang berbeda-beda. Penelitian ini dilakukan pada Lobby Hotel Best Western Premier Jakarta Selatan dengan menggunakan metode kualitatif - deskriptif. Metodologi kualitatif merupakan prosedur yang menghasilkan data deskriptif berupa data tertulis atau lisan di masyarakat Bahasa. Penelitian berfokus pada penggambaran secara menyeluruh tentang bentuk, warna, material, fungsi dari lantai, dinding, plafon lobby hotel Best Western. Hasil dari penelitian ini, pada lobby Hotel Best Western Premier, penggunaan material yang digunakan seperti travertine, karpet, tembaga, akrilik, wallpaper, taco sheet, dan kaca sudah cukup baik dari segi estetika maupun fungsional.
\end{abstract}

Keywords: Penerapan, Material, Lobby, Hotel, Suasana

\section{PENDAHULUAN}

Best Western Premier The Bellevue adalah hotel bintang 4 di Jakarta yang memiliki lokasi yang strategis dan arsitektur unik. Lobby hotel merupakan pusat, sebagai penghubung, serta sebagai jantung pada setiap hotel (Lawson, 2007 p.199; Berens 1997 p.xiii; Curtis 2001, p.8). Berens (1997, p: xiii) menyatakan Lobby hotel merupakan tempat umum dan privasi bertemu. Dengan demikian lobby hotel tidak saja sebagai tempat transaksi, kedatangan tamu, tapi juga sebagai tempat untuk melakukan networking, dan bersosialisasi. Dari sudut pandang ilmu Marketing, lobby hotel didefinisikan sebagai fasilitas fisik dimana jasa dinyatakan, diberikan serta dinikmati (Zeithaml et al., 2006, p.317). Fasilitas fisik disini pernah dinyatakan oleh Bitner (1992) yang mengidentifikasi 3 dimensi servicescapes yaitu: Ambient Conditions, Spatial Layout and functionality, dan Signs, Symbols and Artifacts.

Kotler pada bukunya di tahun 2006 menyimpulkan lingkungan yang disesuaikan dengan servicescapes akan membawa pengaruh pada pengalaman sensorik tubuh. Melalui penglihatan, suara, penciuman, dan sentuhan yang merupakan indera utama pada tubuh manusia. Hal ini akan terlihat pada pengalaman visual (warna, terang/gelap, ukuran, dan bentuk), aural 
(volume suara, pitch), olfactory (aroma, dan kesegaran), dan tactile (kelembutan, kehalusan, temperatur) yang menjadi dimensi lingkungan.

Pada pembahasan spatial layout dan fungsional ruang (Bitner, 1992) fasilitas fisik pada usaha jasa dibuat untuk memenuhi tujuan tertentu dan memuaskan kebutuhan pelanggan dan pekerja. Fasilitas fisik meliputi interior yang di-desain. Lobby yang merupakan focal point hotel yang harus di desain dengan baik agar memberikan kenyamanan dan kesan bagi pengunjung. Mendesain meliputi exterior dan interiornya. Pada penulisan ini difokuskan pada desain lobby yang berfokus pada penggunaan material yang digunakan Hotel Best Western Premier. Hasil akhir yang dituju pada penelitian ini adalah untuk mengetahui material dan penerapan penggunaan material interior pada Lobby Hotel Best Western Premier Jakarta Selatan, serta untuk mengetahui ada tidaknya masalah yang timbul pada penggunaan material tersebut.

Material adalah elemen yang tidak dapat dipisahkan dari ruangan dan dapat membentuk suasana ruang yang diinginkan, memberikan citra positif, kenyamanan, keamanan, dan juga kesan yang tidak terlupakan pada tamu. Beberapa kriteria pokok atau dasar dalam desain interior antara lain fungsi dan tujuan, faedah dan pertimbangan ekonomis, bentuk dan gaya, citra dan pesan.

Hal utama yang perlu menjadi perhatian adalah Persyaratan Bangunan Hotel, yang meliputi :

1. Lantai

Lantai lobby sebagai penunjang harus memenuhi syarat-syarat sebagai berikut yaitu, terbuat dari bahan yang kuat, tahan terhadap benturan, tahan terhadap api, permukaan licin dan mengkilap, mempunyai warna yang ringan, kedap air, permukaan rata, tidak licin, dan mudah dibersihkan.

\section{Dinding}

Dinding lobby sebagai bagian pertama yang dilihat mata harus memenuhi syarat-syarat seperti, terbuat dari bahan yang kuat, tahan lama, tahan terhadap benturan, tahan terhadap api, mudah dibersihkan, kedap air, aman, unsur dekoratif ditekankan pada dinding.

3. Plafon

Plafon lobby sebagai unsur pembentuk dalam ruang harus memenuhi syaratsyarat yaitu, terbuat dari bahan yang kuat, tahan lama, tahan terhadap benturan, tahan terhadap api, mudah 
dibersihkan, mempunyai akustik yang baik.

Setelah mengetahui Persyaratan Bangunan Hotel, dapat dijelaskan lebih rinci sebagai Persyaratan Material, yang meliputi:

1. Lantai

Lantai dapat memberi karakter dan memperjelas sifat ruangan dengan memberikan suatu permainan dari permukaan lantai itu sendiri.

\begin{tabular}{|c|c|c|c|}
\hline Bahan & Karakteristik & Keuntungan & Kerugian \\
\hline Marmer & $\begin{array}{l}\text { Permanent, } \\
\text { Kaku }\end{array}$ & Indah & $\begin{array}{l}\text { Mahal, } \\
\text { Mudah } \\
\text { Kotor, } \\
\text { Keras }\end{array}$ \\
\hline Kayu & $\begin{array}{l}\text {-Alamiah } \\
\text {-Dapat di cat } \\
\text {-Kedap suara }\end{array}$ & $\begin{array}{l}\text {-Tahan lama } \\
\text {-Melentur }\end{array}$ & $\begin{array}{l}\text {-tidak } \\
\text { tahan } \\
\text { terhadap } \\
\text { insekta }\end{array}$ \\
\hline $\begin{array}{l}\text { Ceramic } \\
\text { Tile }\end{array}$ & $\begin{array}{l}\text {-Tahan } \\
\text { Goresan } \\
\text {-kaya akan } \\
\text { bentuk dan } \\
\text { corak }\end{array}$ & $\begin{array}{l}\text {-Tahan lama } \\
\text {-Tidak } \\
\text { mudah } \\
\text { kotor }\end{array}$ & $\begin{array}{l}\text { Tidak } \\
\text { lentur }\end{array}$ \\
\hline Karpet & $\begin{array}{l}\text {-Indah dan } \\
\text { mewah } \\
\text {-simbol } \\
\text { kedudukan } \\
\text {-menciptakan } \\
\text { suasana } \\
\text { hangat }\end{array}$ & $\begin{array}{l}\text {-menjadi } \\
\text { elemen } \\
\text { akustik } \\
\text { - } \\
\text { pemeliharaa } \\
\text { n mudah } \\
\text { dan murah } \\
\text {-corak dan } \\
\text { warna tidak } \\
\text { terbatas }\end{array}$ & $\begin{array}{l}\text { - dapat } \\
\text { menimbu } \\
\text { Ikan } \\
\text { problem } \\
\text { listrik } \\
\text { - } \\
\text { membutu } \\
\text { hkan } \\
\text { keahlian } \\
\text { khusus }\end{array}$ \\
\hline
\end{tabular}

\section{Dinding}

Dinding adalah suatu bidang nyata yang membatasi suatu ruangan atau membatasi antar kegiatan atau fungsi yang berbeda, melindungi terhadap pengaruh cuaca.
Berikut adalah bahan-bahan penutup

dinding:

Tabel 2: Material Dinding

\begin{tabular}{|c|c|c|}
\hline Bahan & Jenis & $\begin{array}{c}\text { Kekuatan dan } \\
\text { ketahanan }\end{array}$ \\
\hline Batu & $\begin{array}{l}\text { batu alam, } \\
\text { asbes, } \\
\text { coraltex, } \\
\text { marmer } \\
\end{array}$ & $\begin{array}{l}\text {-kuat, tahan } \\
\text { panas/dingin. Air, AC }\end{array}$ \\
\hline Cat & $\begin{array}{l}\text { cat tembok, } \\
\text { cat semprot }\end{array}$ & $\begin{array}{l}\text {-relatif singkat } 1-2 \\
\text { tahun } \\
\text {-tidak tahan panas, } \\
\text { beberapa tahan air dan } \\
\text { AC }\end{array}$ \\
\hline Fiberglass & $\begin{array}{l}\text { Flexiglass, } \\
\text { paraglass }\end{array}$ & $\begin{array}{l}\text {-tahan retak, getaran } \\
\text { keras, benturan, air } \\
\text { dan } A C\end{array}$ \\
\hline Gelas & Cermin, kaca & $\begin{array}{l}\text {-kuat segala cuaca } \\
\text {-tidak tahan getaran } \\
\text {-tahan air dan AC }\end{array}$ \\
\hline Kayu & $\begin{array}{l}\text {-tripleks, } \\
\text { papan } \\
\text {-bambu/bilik } \\
\text {-rotan } \\
\end{array}$ & $\begin{array}{l}\text {-kuat terhadap cuaca } \\
\text {-tidak tahan air } \\
\text {-kuat terhadap AC }\end{array}$ \\
\hline Metal & $\begin{array}{l}\text {-stainless } \\
\text { sheet } \\
\text {-chrom } \\
\text {-aluminium }\end{array}$ & $\begin{array}{l}\text {-awet, tahan cuaca } \\
\text {-tahan air dan tidak } \\
\text { karat } \\
\text {-tahan AC }\end{array}$ \\
\hline
\end{tabular}

3. Plafon

Plafon dapat didefinisikan sebagai

bidang penutup atau pembatas dari

sebuah ruang dalam yang telah tebentuk

antara bidang alas dan dinding-dinding

yang ada pada keempat sisinya.

Tabel 3: Material Plafon

\begin{tabular}{|l|l|}
\hline $\begin{array}{l}\text { Jenis Bahan } \\
\text { Penutup } \\
\text { Plafon }\end{array}$ & Karakteristik \\
\hline Gypsum & $\begin{array}{l}\text { Tahan terhadap api , tidak tahan } \\
\text { terhadap air. } \\
\text { Berstektur licin, dapat dicat/ } \\
\text { dilapis dengan wallpaper. } \\
\text { Dapat meredam suara bising. }\end{array}$ \\
\hline
\end{tabular}




\begin{tabular}{|l|l|}
\hline Triplek & $\begin{array}{l}\text { Tahan terhadap api, tidak tahan } \\
\text { terhadap air. } \\
\text { Berstektur kasar, dapat dicat/ } \\
\text { dilapis dengan wallpaper. } \\
\text { Biasanya terlihat modul triplek. }\end{array}$ \\
\hline $\begin{array}{l}\text { Acoustic } \\
\text { Panel }\end{array}$ & $\begin{array}{l}\text { Berfungsi sebagai peredam suara. } \\
\text { Kuat dan tahan lama. }\end{array}$ \\
\hline Protective & $\begin{array}{l}\text { Merupakan panel langit-langit } \\
\text { yang dilapisi dengan pelindung } \\
\text { khusus seperti aluminium foil } \\
\text { PVC, dll. } \\
\text { Pelindung kelembaban. }\end{array}$ \\
\hline
\end{tabular}

\section{METODE}

Berdasarkan pada tujuan penelitian yang ingin dicapai, penelitian ini akan memaparkan jenis material, serta penggunaan yang mengambil objek penelitian material pada lantai, dinding, dan plafon Lobby Hotel Best Western Premier Jakarta Selatan yang berlokasi di Jl. H. Nawi no. 1 Pondok Indah, Jakarta Selatan.

Penelitian ini merupakan penelitian deskriptif-kualitatif. Fokusnya adalah penggambaran secara menyeluruh tentang bentuk, warna, material, fungsi dari lantai, dinding, plafon lobby hotel Best Western.

$$
\text { Penelitian kualitatif harus }
$$
mempertimbangkan metodologi kualitatif itu sendiri. Metodologi kualitatif merupakan prosedur yang menghasilkan data deskriptif berupa data tertulis atau lisan di masyarakat Bahasa.

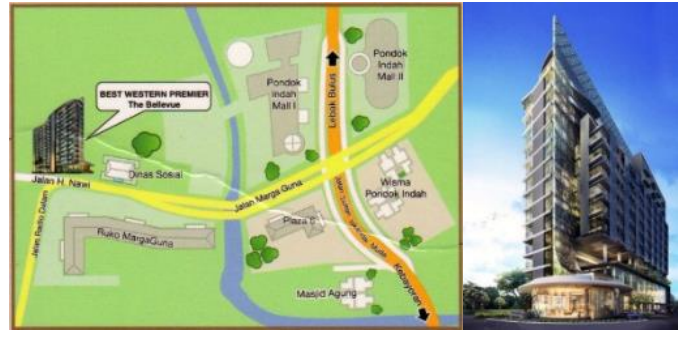

Gambar 1. Lokasi Hotel Best Western Premier, Pondok Indah

\section{HASIL DAN PEMBAHASAN}

\section{Material pada Lobby Hotel Best Western}

\section{Jakarta Selatan}

A. Material pada Lantai Lobby Hotel Best Western

Pada bagian lantai Lobby Hotel Best Western, penggunaan batu dengan jenis travertine digunakan sebagai bahan penutup lantai. Travertine yang digunakan berwarna beige sebagai warna dominan dan warna hitam sebagai warna aksen. Pada area resepsionis, terdapat permainan pola pada lantai dengan menggunakan motif kawung. Motif yang digunakan menggunakan travertine berwarna hitam yang di proses dengan laser cutting sesuai dengan pola kawung.

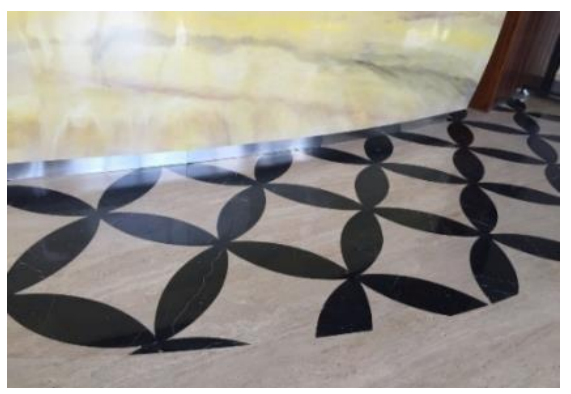

Gambar 2 . Travertine dengan motif pola Kawung (sumber: dok. Tim) 
Penggunaan material lantai pada area tunggu di lobby Hotel Best Western Jakarta Selatan, terdapat perbedaan jenis lantai. Karpet berwarna hijau dengan motif fraktual menjadi pilihan sebagai bahan penutup lantai pada area tunggu.

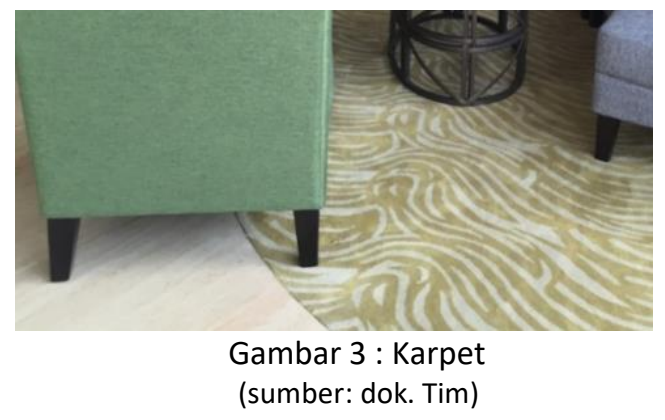

B. Material pada Dinding Lobby Hotel Best Western

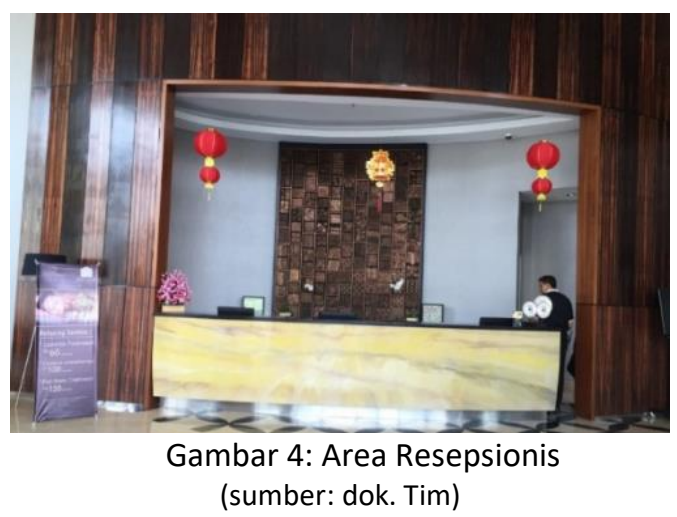

Pada area dalam resepsionis, dinding menggunakan wallpaper berwarna abuabu dan pada bagian tengah, dinding menggunakan cetakan motif batik yang terbuat dari bahan tembaga dan dijadikan sebagai elemen dekoratif dinding. Tembaga yang dicetak, mempunyai motif batik yang berbedabeda tetapi motif yang digunakan berasal dari motif batik Jawa.

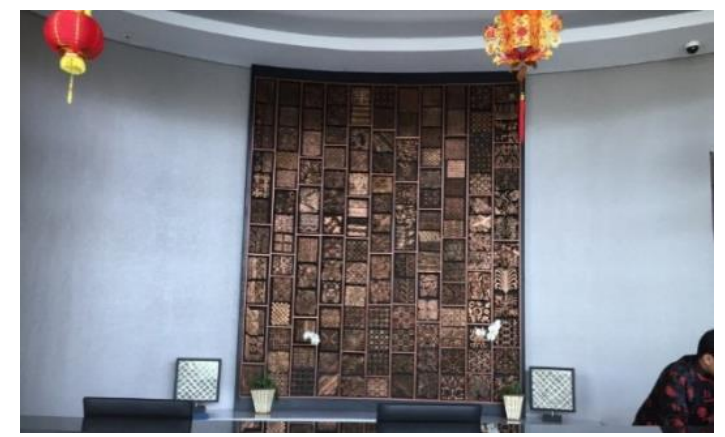

Gambar 5 : Dinding Resepsionis (sumber: dok. Tim)

Sedangkan bagian luar area resepsionis, dinding menggunakan bahan taco sheet yang memberikan permainan urat kayu dan warna kayu yang berbeda.

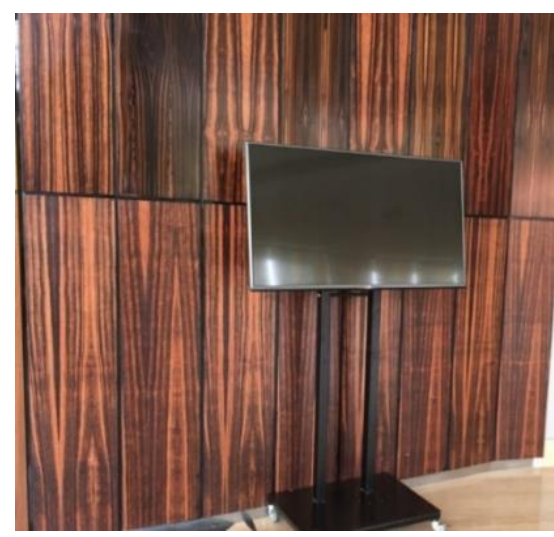

Gambar 6 : Dinding Taco Sheet (sumber: dok. Tim)

Partisi sebagai pembatas area, menggunakan material tembaga yang di cat berwarna coklat dan disusun melengkung dari lantai sampai plafon. Pada bagian kolom, kolom menggunakan akrilik yang dilapisi dengan tembaga yang 
di cutting motif batik. Pada bagian kolom terdapat lampu sehingga jika lampu dinyalakan terdapat cahaya yang keluar dari akrilik yang bermotif batik tersebut.

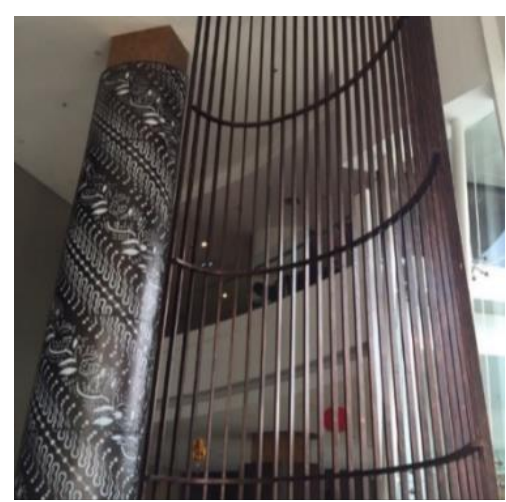

Gambar 7 : Kolom dan Partisi (sumber: dok. Tim)

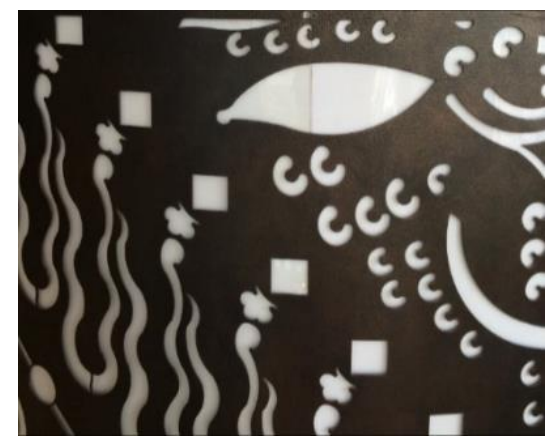

Gambar 8 : Tembaga dan Akrilik (sumber: dok. Tim)

Dinding pada fasad Lobby Hotel Best Western, menggunakan kaca tempered glass dan sebagai penguat bangunan menggunakan besi yang di cat berwarna putih.

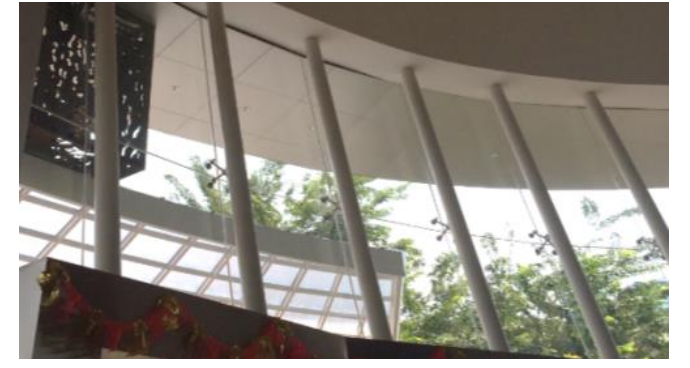

Gambar 9 : Kaca dan Besi (sumber: dok. Tim)

C. Material pada Plafon Lobby Hotel Best Western

Bahan yang digunakan untuk plafon menggunakan gypsum yang di finishing cat berwarna putih. Pada area tunggu, bagian plafon menggunakan black mirror yang berbentuk oval.

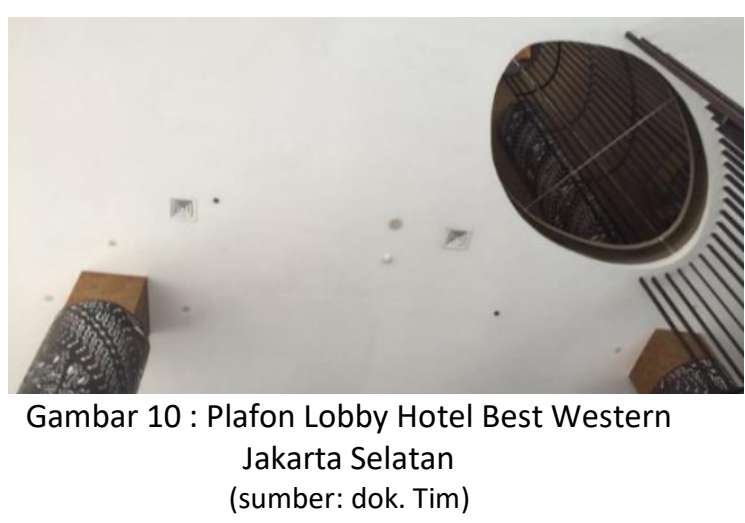

\section{Penerapan Material pada Lobby Hotel Best}

\section{Western Jakarta Selatan}

\section{A. Penerapan Material pada Lantai Lobby} Hotel Best Western

Penggunaan travetine pada lantai menimbulkan kesan yang mewah pada lobby karena sifatnya yang mengkilap dan mahal. Dari segi estetika, travertine 
ini memiliki warna dan pattern yang berbeda-beda yang dapat memperindah ruangan. Teksturnya halus dan memiliki gradasi warna yang lembut menjadikan lobby hotel lebih terlihat eksklusif dan mewah. Warna beige yang digunakan pada lantai, memberikan kesan yang natural dan netral yang mendukung tema lobby hotel Best Western Jakarta Selatan. Sesuai dengan tema hotel yaitu "Jawa Modern" motif kawung juga digunakan pada lantai ini. Dari segi fungsional, travertine merupakan bahan yang kuat dan tahan api, tahan benturan, permukaan mengkilap, permukaan rata, mempunyai warna yang ringan, dan kedap air.

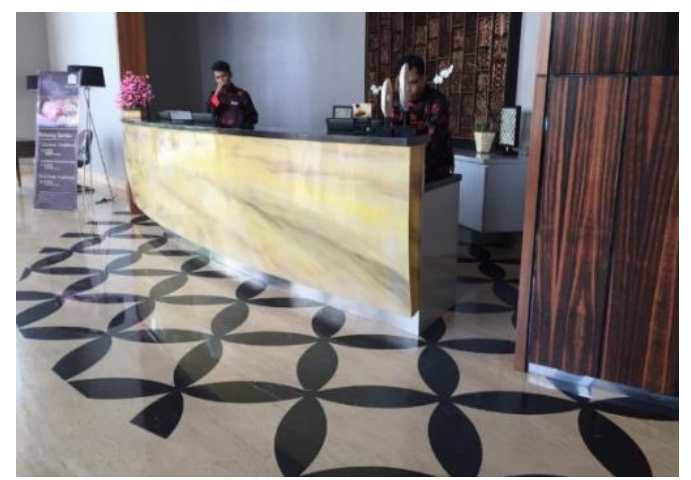

Gambar 11: Lantai Area Resepsionis Lobby Hotel Best Western, Jakarta Selatan (sumber: dok. Tim)

Penggunaan karpet pada area tunggu lobby, dapat menciptakan suasana yang hangat dan nyaman bagi tamu karena teksturnya yang lembut. Dari segi estetika, karpet ini memiliki motif yang tidak beraturan sehingga menjadikannya unik, mewah, dan indah. Warna yang digunakan juga memberikan kesan yang tenang dan sejuk bagi tamu yang sedang menunggu. Dari segi fungsional, karpet memenuhi syarat sebagai bahan yang tahan benturan, cukup kuat, tidak licin, mempunyai warna yang ringan, mempunyai permukaan rata, dan dapat menjadi elemen akustik.

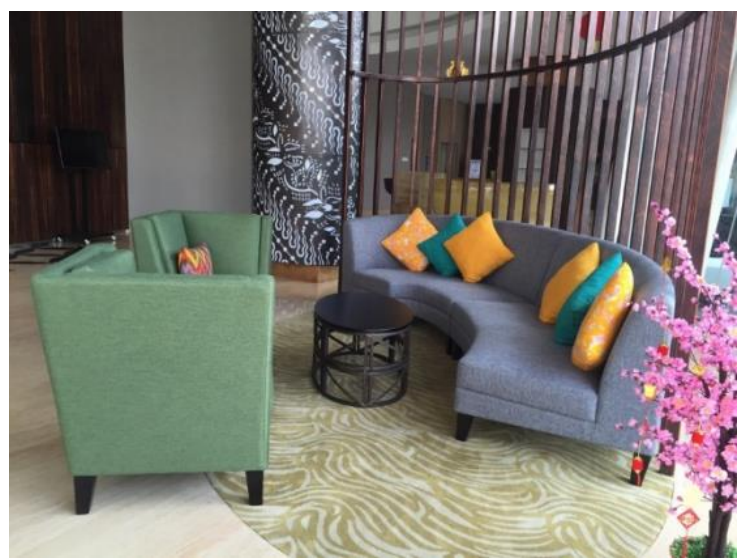

Gambar 12 : Lantai Area Tunggu Lobby Hotel Best Western, Jakarta Selatan (sumber: dok. Tim)

\section{B. Penerapan Material pada Dinding Lobby} Hotel Best Western

Penggunaan wallpaper pada dinding dapat menimbulkan kesan yang mewah pada lobby hotel dilihat dari motif maupun tekstur dan warna wallpaper yang digunakan. Dari segi estetik, wallpaper yang digunakan ini dapat menjadi penetral diantara material 
dinding lain yang mempunyai motif yang beragam. Bila diamati lebih dekat, wallpaper ini mempunyai motif vertikal dengan menggunakan warna abu-abu gelap yang mengkilap. Dari segi fungsional, wallpaper merupakan bahan yang cukup kuat, tahan benturan, tahan lama, perawatan mudah, dan aman.

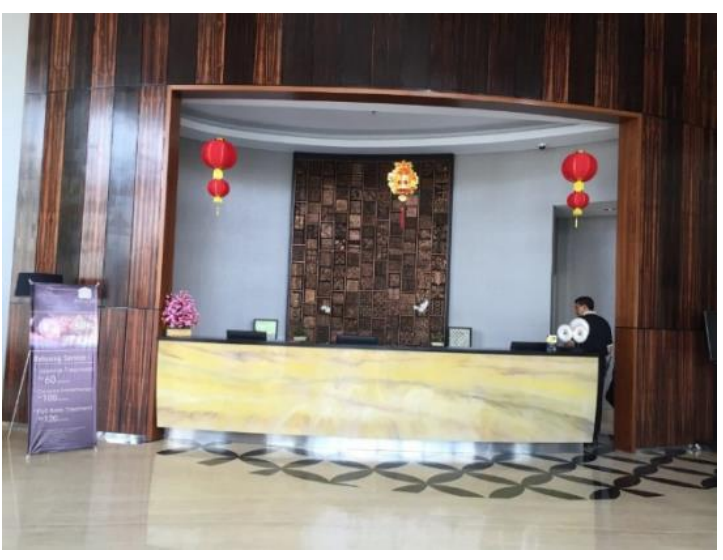

Gambar 13: Dinding Area Resepsionis Lobby Hotel Best Western, Jakarta Selatan (sumber: dok. Tim)

Penggunaan tembaga dan warna pada lobby hotel ini dapat menciptakan suasana Jawa apalagi ditambah dengan motif batik. Dari segi estetika, tembaga memiliki warna yang mencerminkan citra yang eksklusif dan modern pada lobby. Keindahan tembaga yang digunakan tercermin dari motif-motif batik pada area resepsionis dan menjadi focal point pada lobby. Dari segi fungsional, tembaga merupakan bahan yang kuat, tahan benturan, mudah benturan, tahan terhadap cuaca, tahan terhadap api, tahan lama, kedap air, aman, dan terdapat unsur dekoratif.

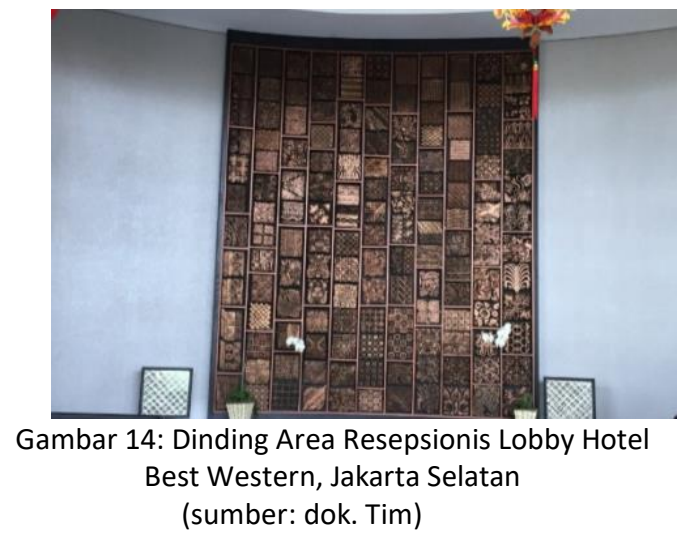

Pada bagian kolom, penggunaan tembaga juga digunakan dengan mengkombinasikan antara tembaga dan akrilik. Dari segi estetika, akrilik yang bersifat tembus pandang dapat memberikan cahaya jika lampu dinyalakan. Cahaya yang keluar dari akrilik menjadi suatu elemen estetis karena menciptakan pancaran cahaya sesuai dengan motif batik pada tembaga. Dari segi fungsional, akrilik merupakan bahan yang kuat, tahan terhadap cuaca, tahan lama, kedap air, dan aman. 


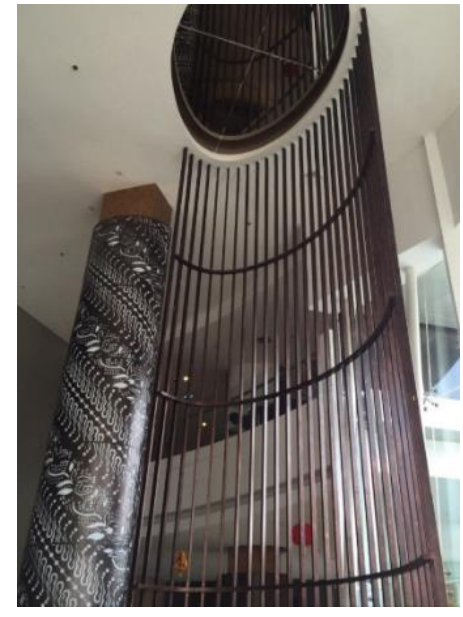

Gambar 15: Kolom dan Partisi Area Tunggu Lobby Hotel Best Western, Jakarta Selatan (sumber: dok. Tim)

\section{Penerapan Material pada Plafon Lobby}

\section{Hotel Best Western}

Penggunaan gypsum yang di finishing cat tembok berwarna putih pada plafon, dapat menimbulkan kesan yang bersih dan luas pada lobby hotel. Dari segi estetik, gypsum yang di cat berwarna putih dapat menjadi penetral antara material yang digunakan pada lantai dan dinding lobby hotel Best Western Jakarta Selatan. Selain itu, warna putih yang digunakan pada plafon, dapat memberikan suasana yang tenang. Dari segi fungsional, gypsum merupakan bahan yang tahan lama, tahan terhadap benturan, mudah dalam perawatan, mempunyai aksutik yang baik, dan tahan terhadap api.

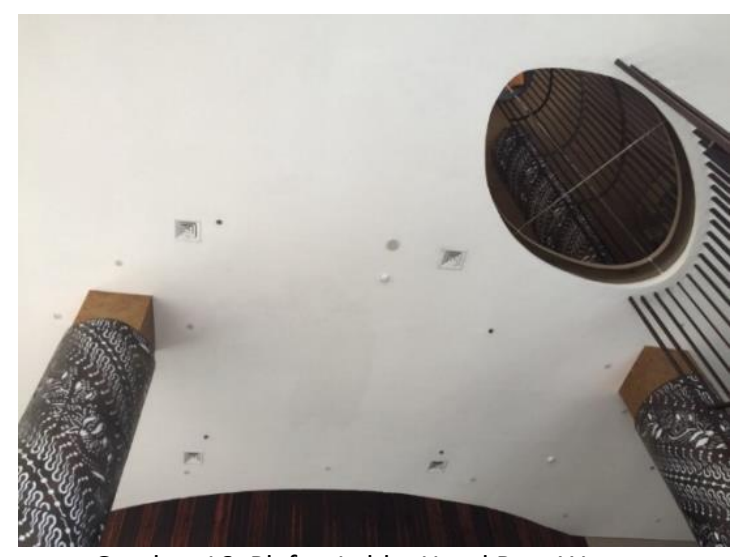

Gambar 16: Plafon Lobby Hotel Best Western Jakarta Selatan (sumber: dok. Tim)

Penggunaan black mirror pada plafon, dapat menimbulkan kesan yang luas pada lobby hotel. Dari segi estetik, black mirror yang di cutting berbentuk oval sesuai dengan layout area tunggu menjadikan kaca ini memiliki daya tarik tersendiri. Partisi dibuat seperti menembus plafon sehingga memberikan kesan tinggi pada plafon. Warna kaca yang gelap juga memberikan kesan yang elegan dan mewah pada langit-langit lobby Hotel Best Western Jakarta Selatan. Dari segi fungsional, kaca merupakan bahan yang mudah dalam perawatan, kuat terhadap segala cuaca, dan tahan terhadap api. 
Masalah yang Timbul Dalam Penerapan

\section{Material pada Lobby Hotel Best Western}

Jakarta Selatan

\section{A. Lantai}

Masalah yang timbul dari penggunaan lantai lobby Hotel Best Western Jakarta terdapat pada penggunaan travertine. Material ini sulit dibersihkan bila terkena noda sehingga meninggalkan bekas. Karena bahannya yang mengkilap, maka bahan ini harus dibersihkan dengan baik sehingga tidak meninggalkan debu yang menutupi lantai.

Selain itu, penggunaan karpet perlu diperhatikan dalam perawatannya karena karpet yang digunakan ditempel pada lantai sehingga tidak mudah dibersihkan bila terkena noda. Warna yang terang lebih mudah terlihat kotor.

\section{B. Dinding}

Pemasangan wallpaper yang kurang rapi pada dinding lobby hotel menyebabkan adanya gelembung-gelembung yang jelas pada dinding dan juga terlihat sambungan antar wallpaper yang digunakan. Hal ini mengurangi nilai estetika dari hotel itu sendiri karena tidak nyaman dipandang mata.
Pengunaan akrilik pada kolom lobby hotel tidak rapi karena sambungan antar akrilik terlihat jelas dan penempelan akrilik yang kurang baik sehingga akrilik terlihat dalam keadaan terbuka. Bahan ini juga sulit dibersihkan karena dilapisi oleh tembaga bermotif batik.

\section{Plafon}

Penggunaan gypsum yang difinishing cat berwarna putih, dapat mudah terlihat kotor karena warnanya yang bersih. Gypsum yang digunakan pada plafon memiliki kekurangan yaitu mudah menyerap air.

Penggunaan black mirror pada plafon memiliki kekurangan yaitu tidak tahan terhadap getaran dan sulit dibersihkan karena letaknya yang tinggi.

\section{SIMPULAN}

Pemilihan material sangat penting dalam lobby hotel karena dapat membentuk suasana yang diinginkan ruangan tersebut. Penggunaan material yang baik dari segi estetik maupun fungsional tentunya dapat memberi kenyamanan dan kesan positif bagi tamu.

Pada lobby Hotel Best Western Premier, penggunaan material yang digunakan seperti travertine, karpet, tembaga, akrilik, 
wallpaper, taco sheet, dan kaca sudah cukup baik dari segi estetika maupun fungsional, namun masih ada beberapa hal yang perlu diperhatikan, seperti pemasangan material, penempatan material, dan perawatan material.

\section{DAFTAR PUSTAKA}

Bitner,M.J. 1992. Servicescape: the impact of physical surroundings on customers and employees. Journal of Marketing 56 (April), p.57-71. Date retrieved: 17.06.2015.

Lawson, Fred (1980). Hotels, Motels, Condominiums. Great Britain: The Architectural Press Ltd. 1976.

Letitia R.A., Giovanni Angelina., (2015) Laporan Penulisan Mata Kuliah Seminar: Analisa Penerapan Material Pada Lobby Hotel Best Western Premier Jakarta Selatan, Jakarta.

Zeithaml V.A., Bitner, M.J. and Gremler D.D.. (2006). Services Marketing: Integrating Customer Focus Across the Firm. 4th Ed. McGrawHill: NewYork. 